Instituto de Química - Universidade de SÃo PaUlo

\title{
BicAMAdAS CATIÔNICAS EM SÍliCA: AdSORÇão E ESTABILIDADE COLOIDAL A BAIXA FORÇA IÔNICA
}

\author{
SÉrgio de Paula Moura
}

DisSERTAÇÃO DE MESTRADO EM BIOQUÍMICA

Orientadora: Ana Maria Carmona-Ribeiro

Trabalho desenvolvido no Laboratório de Biocolóides
do Departamento de Bioquímica do IQUSP

São Paulo

2003 


\section{Resumo}

O desafio de romper a estrutura rígida fechada de vesículas quando em contato com partículas de silica foi circundado com o uso de dispersões de brometo dioctadecildimetilamônio (DODAB) compostas de fragmentos nanométricos abertos de bicamadas ao invés de vesículas. A afinidade de fragmentos de bicamadas de DODAB por superfícies carregadas de sílica foi até o momento avaliada principalmente do ponto de vista de variações de $\mathrm{pH}$ e temperatura através do uso de isotermas de adsorção. $\mathrm{O}$ presente projeto procura estabelecer uma relação de afinidade sobre o ponto de vista da variação da força iônica do meio. Como em trabalhos anteriores, isotermas de adsorção foram utilizadas para determinar a quantidade de DODAB adsorvido na superfície sólida de sílica. Uma nova técnica de medição dos potenciais-zeta e tamanhos médios das partículas permitiu a determinação quantitativa desses valores para os sistemas empregados. Em seguida definiu-se um novo parâmetro chamado de R utilizado para identificar o grau de recobrimento por bicamadas sobre as partículas de sílica. Em baixa força iônica e pH 6.5, a adsorção de DODAB a partir de fragmentos de bicamadas na sílica foi quantificada por isotermas de adsorção a $0,0.1,0.5$ e $1.0 \mathrm{mM}$ de $\mathrm{KCl}$ ou TRIS-HCl. A adsorção de DODAB aumentou em função da concentração de sal à medida que a densidade de carga superficial das partículas se elevava. A forma apresentada pelas isotermas foi típica de adsorção competitiva com um pico máximo, possivelmente devido à atração hidrofóbica entre fragmentos adsorvidos e fragmentos livres. Sendo que a adsorção de DODAB na sílica ocorre na forma de pequenos discos bidimensionais de bicamadas, os fragmentos aparentemente não se fecham em uma forma única de bicamada contínua recobrindo a partícula, ao invés disso interagiam através de suas bordas hidrofóbicas com os fragmentos livres em dispersão. Em $\mathrm{pH}$ 6.5, ao longo de uma faixa de concentração de DODAB $(0$ - $1.0 \mathrm{mM})$ e de $\mathrm{KCl}(0.1-10.0 \mathrm{mM})$, a partir da medição dos tamanhos de partícula, análise dos potenciais-zeta, fotografias das misturas e cinéticas de sedimentação de partículas, pode-se concluir que a estabilidade coloidal das partículas nas misturas foi governada pelo fator $R$, que é a relação de áreas superficiais totais para bicamadas $A b$ e partículas $A p, R=A b / A p$. Em $\mathrm{R} \sim 0.5$, o potencial-zeta médio $(\zeta)$ foi zero, o diâmetro médio de partícula (Dz) foi o máximo medido, a sedimentação foi rápida e a estabilidade coloidal estava em um nível mínimo; em $\mathrm{R}>1$, o $\zeta$ medido passou a ser positivo, Dz foi minimizado, a sedimentação não ocorreu e a estabilidade coloidal estava em um nível máximo. Em baixa força iônica, foi alcançada uma alta estabilidade coloidal de partículas na presença de fragmentos de bicamadas catiônicas para valores de $\mathrm{R}$ iguais ou maiores que 1, que represente o estado de equivalência de áreas totais entre fragmentos de bicamadas e partículas. 


\begin{abstract}
The challenge of breaking open rigid bilayer vesicles upon contact with silica particles was circumvented by using a dioctadecyldimethylammonium bromide (DODAB) dispersion consisting of open, nanosized bilayer fragments instead of vesicles. The affinity of DODAB bilayer fragments for charged silica surfaces was at the moment evaluated through the $\mathrm{pH}$ and temperature point of view by using adsorption isotherms as analytical technique. The present project seeks to establish an affinity relation between DODAB and silica through the ionic strength point of view. Similarly to previous work, adsorption isotherms were used to quantify the amount of DODAB adsorbed on the silica particle surface. A new technique for the measurement of zeta-potentials and mean particle diameters was also employed. A new parameter defined as $\mathrm{R}$ was used to identify the level of bilayer covering over the surface of silica. At low ionic strength and $\mathrm{pH}$ 6.5, DODAB adsorption from bilayer fragments on silica was quantified from adsorption isotherms at $0,0.1,0.5,1.0$ and $10.0 \mathrm{mM}$ of $\mathrm{KCl}$ or TRIS-HCl. Adsorption increased as a function of salt concentration and surface charge density on particles. Isotherms shape was typical of competitive adsorption with a maximum possibly due to hydrophobic attraction between adsorbed and free bilayer fragments. Upon adsorption as flat patches on particles, the fragments did not apparently seal into a continuous and closed bilayer surrounding the particle, instead interacted via hydrophobic edges with free fragments in dispersion. At $\mathrm{pH}$ 6.5, over a range of DODAB $(0-1.0 \mathrm{mM})$ and $\mathrm{KCl}$ concentrations $(0.1-10.0 \mathrm{mM})$, from particle sizing, zetapotential analysis, photographs of the mixtures and particle sedimentation kinetics, colloid stability of particles in the mixtures was governed by the ratio $\mathrm{R}$ of total surface areas for bilayers $\mathrm{Ab}$ and particles $\mathrm{Ap}, \mathrm{R}=\mathrm{Ab} / \mathrm{Ap}$. At $\mathrm{R} \sim 0.5$, mean zeta-potential $(\zeta)$ was zero, mean particle diameter $(\mathrm{Dz})$ was at maximum, sedimentation was rapid and colloid stability was at minimum; at $\mathrm{R}>1, \zeta$ was positive, Dz was minimized, sedimentation was absent and colloid stability was high. At low ionic strength, high colloid stability for particles in presence of cationic bilayer fragments was achieved at or above $\mathrm{R}=1$, i.e., from the equivalence of total surface areas for bilayer fragments and particles.
\end{abstract}




\section{ÍNDICE}

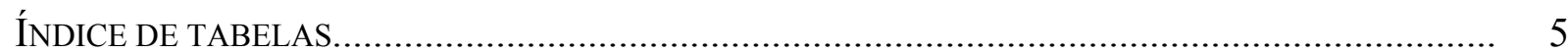

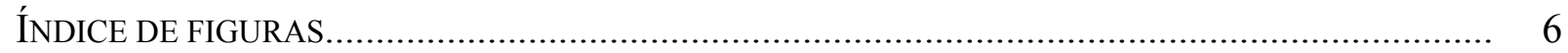

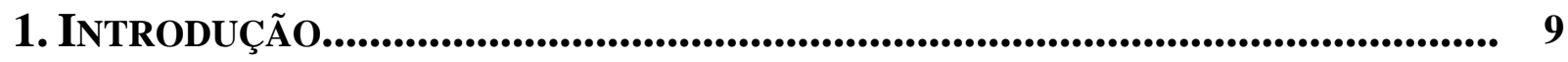

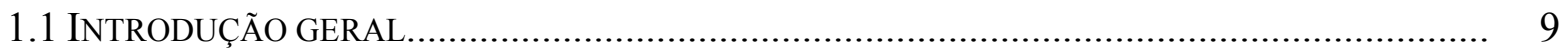

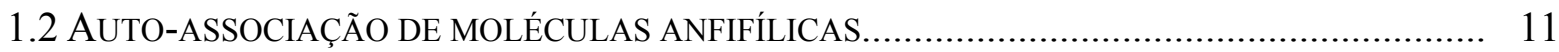

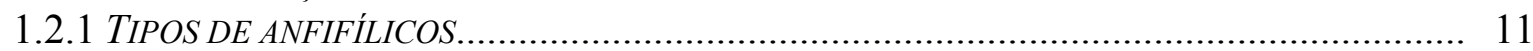

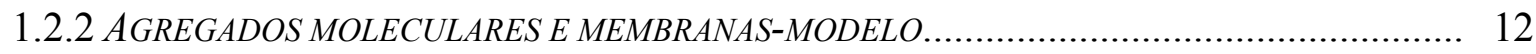

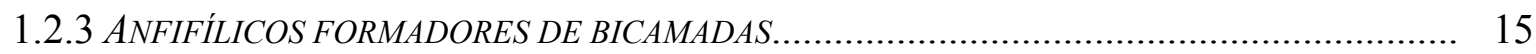

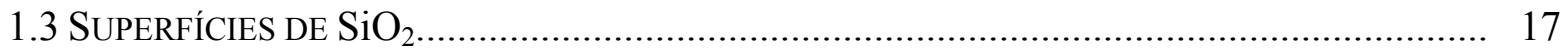

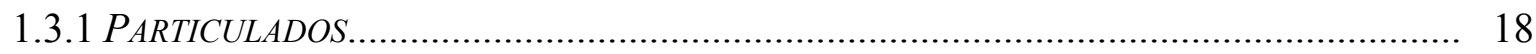

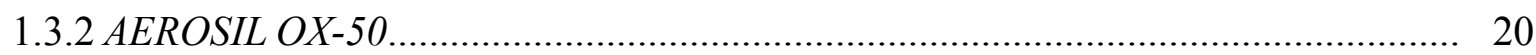

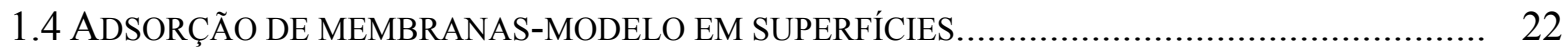

1.4.1 ASPECTOS FÍSICO-QUÍMICOS DA ADSORÇÃO EM SUPERFÍCIES .................................... 22

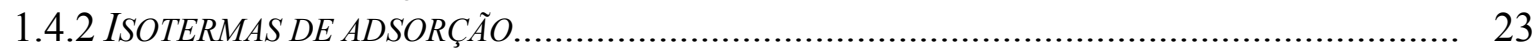

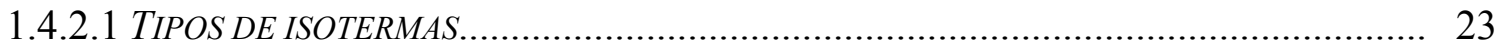

2. MATERIAIS E MÉTODOS............................................................... 28

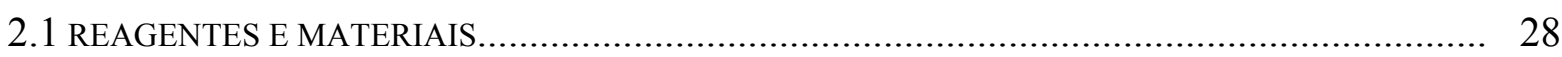

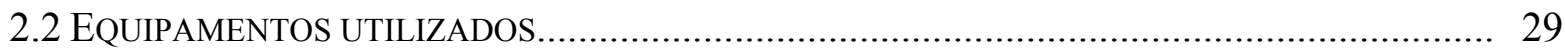

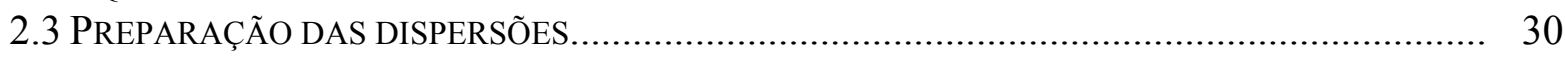

2.3.1 OBTENÇÃO DE ANFIFÍLICOS E PREPARAÇÃO DE VESÍCULAS.................................... 30

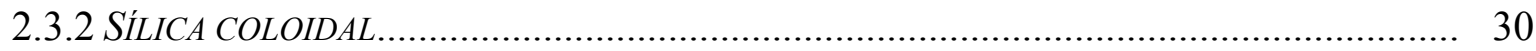

2.4 MÉTODOS ANALÍTICOS PARA A DETERMINAÇÃO DA CONCENTRAÇÃO DE DODAB.......... 30

2.4.1 DETERMINAÇÃO DA CONCENTRÃO POR MICROTITULAÇÃO....................................... 30

2.4.2 DETERMINAÇÃO DA CONCENTRAÇÃO POR COLORIMETRIA........................................... 31

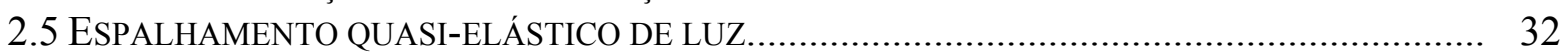

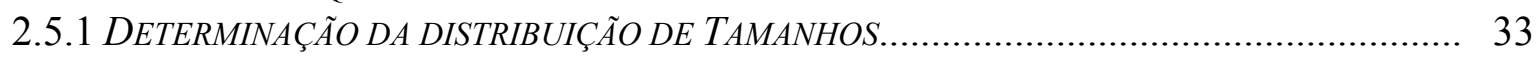

2.5.2 DETERMINAÇÃO DO POTENCIAL-ZETA _................................................................... 34

2.6 INTERAÇÃO ENTRE AS VESÍCULAS DE DODAB E AS PARTÍCULAS DE SÍLICA.................... 36

2.6.1 DETERMINAÇÃO DO TAMANHO E DO POTENCIAL-ZETA DAS PARTÍCULAS.......................... 37

2.6.2 DETERMINAÇÃO DA AGREGAÇÃO DAS PARTÍCULAS POR TURBIDEZ OU SEDIMENTAÇÃO... 37

2.7 DETERMINAÇÃO DA ADSORÇÃO DE BICAMADAS SOBRE AS PARTÍCULAS DE SÍLICA.......... 39

3. RESULTADOS E DISCUSSÃO................................................................................... 40

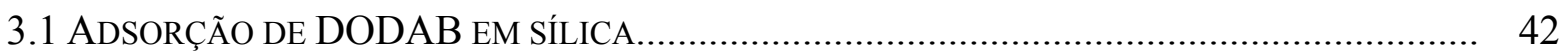

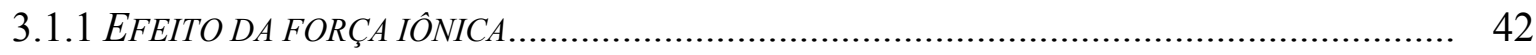

3.1.2 EFEITO DA DENSIDADE DE CARGA DA PARTÍCULA.................................................... 43

3.2 ESTABILIDADE COLOIDAL E RAZÃO ENTRE ÁREAS TOTAIS DE BICAMADA E PARTÍCULAS 45

4. CONCLUSÕES........................................................................................... 48

5. PERSPECTIVAS.......................................................................................... 48

6. REFERÊNCIAS BIBLIOGRÁFICAS............................................................49

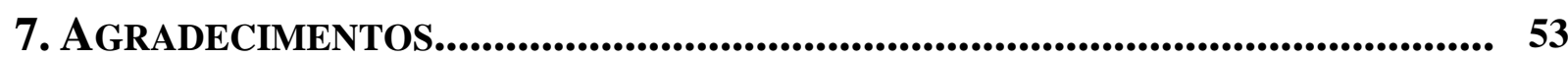




\section{ÍNDICE DE TABELAS}

Tabela 1.2.2.1 - Agregados supramoleculares de anfifílicos.

página 14

Tabela 2.4.2.1 - Leituras e correção de leituras de absorbância pelo método do Brij para curva padrão de DODAB. Curva padrão.

página 31

Tabela 2.4.2.2 - Doseamento da dispersão de vesículas de DODAB obtidas por aquecimento em presença de $\mathrm{KCl} 1 \mathrm{mM}$. Leituras e correção de leituras de absorbância pelo método de Brij.

página 32

Tabela 2.7.1 - Protocolo para determinação das isotermas de adsorção entre vesículas de DODAB e partículas de sílica em presença de força iônica de $\mathrm{KCl}$.

página 39

Tabela 2.7.2 - Planilha para calcular a quantidade de moléculas de DODAB adsorvidas por metro quadrado de sílica.

página 40 


\section{ÍNDICE DE FIGURAS}

Figura 1.1.1 - Exemplo de biofuncionalização de uma superfície sólida. O receptor utilizado é o monosialogangliosídio GM1, um glicolípide, o qual se insere na bicamada lipídica depositada sobre uma superfície sólida (substrato), e é reconhecido pela toxina da cólera [Carmona-Ribeiro, 2001].

Página 10

Figura 1.1.2 - Uma seqüência de deposição de vesículas lipídicas esféricas em sílica hidrofílica acompanhada com o uso de um microscópio de força atômica [Jass et al., 2000]. Página 11

Figura 1.2.1.1 - Estrutura molecular do brometo de dioctadecildimetilamônio (DODAB), um anfifílico sintético catiônico dialquil de cadeia longa, capaz de se auto-associar formando bicamadas.

página 11

Figura 1.2.3.1 - Crio-TEM (microscopia eletrônica de transmissão) de fragmentos de DODAB obtidos por sonicação. Somente fragmentos de bicamadas de DODAB são encontrados em solução. A barra no lado direito superior da imagem representa $100 \mathrm{~nm}$ de tamanho [Andersson et al., 1995].

página 17

Figura 1.3.1 - Silanol e siloxano, principais grupos encontrados na superfície de $\mathrm{SiO}_{2}$. página 18

Figura 1.3.1.1 - Dissociação dos grupos silanóis na superfície das partículas AEROSIL. página 19

Figura 1.3.1.2 - Densidade superficial de carga em função do $\mathrm{pH}$ para $\mathrm{SiO}_{2}$ em 4 diferentes concentrações de $\mathrm{KCl}$ [Tadros \& Lyklema, 1968].

página 20

Figura 1.3.1.3 - Dupla-camada elétrica ao redor de uma partícula negativamente carregada, definição de potencial-zeta.

página 20

Figura 1.3.2.1 - TEM de AEROSIL OX-50. Como se pode perceber, os diâmetros das partículas se apresentam efetivamente em uma faixa extensa, o que resulta em uma elevada polidispersidade.

página 21

Figura 1.3.2.2 - Representação da formação de pontes de hidrogênio entre partículas (A) e aglomeração dos agregados em uma rede tridimensional macroscópica (B).

página 21

Figura 1.4.2.1.1 - Sistema de classificação de Isotermas.

página 24 
Figura 2.5.1.1 - Relatório padrão de medição da distribuição de tamanhos de vesículas de DODAB a $2 \mathrm{mM}$ e partículas de sílica a $0.5 \mathrm{mg} / \mathrm{ml}$, ambas em água, obtido no ZetaPlus. página 34

Figura 2.5.2.1 - Sistema óptico utilizado na medição do potencial-zeta. página 35

Figura 2.5.2.2 - Relatório padrão de medição do potencial-zeta de vesículas de DODAB a 2 $\mathrm{mM}$ e partículas de sílica a $0.5 \mathrm{mg} / \mathrm{ml}$, ambas em água, obtido no ZetaPlus. página 36

Figura 2.6.2.1 - Determinação da cinética de sedimentação de sílica em presença de DODAB com o uso da balança de sedimentação de um dinamômetro.

página 38

Figura 3.1 - Representação esquemática da maneira como um fragmento de bicamada se deposita sobre a superfície de sílica. A ação da força eletrostática é representada pelas cargas + e - de cada espécie.

página 41

Figura 3.2 - Representação do processo de estabilização de partículas pequenas de sílica perfeitamente recobertas por bicamadas de DODAB. A área superficial de bicamadas deve ser igual à área superficial de sílica.

página 41

Figura 3.1.1.1 - Adsorção de DODAB por metro quadrado de sílica $(1 \mathrm{mg} / \mathrm{ml})$ em soluções com 0 (A), 0.1 (B), 0.5 (C) e $1.0 \mathrm{mM}$ (D) de $\mathrm{KCl}$ ou Tris- $\mathrm{HCl}$ a pH 6.3, $25{ }^{\circ} \mathrm{C}$. A linha pontilhada representa a adsorção esperada para a deposição de uma única bicamada de DODAB em cada partícula de sílica, tomando $0.6 \mathrm{~nm}^{2}$ como a área da cabeça polar de cada molécula de DODAB adsorvida na superfície.

Página 42

Figura 3.1.1.2 - Fórmula do TRIS- $\mathrm{HCl}(\mathrm{pKa}=8.08)$.

Página 43

Figura 3.1.2.1 - Decréscimo exponencial da adsorção de DODAB em função da densidade de carga superficial das partículas de sílica em quatro diferentes concentrações de DODAB restantes no sobrenadante ("Free" DODAB concentration). Os símbolos brancos representam dados obtidos anteriormente e os símbolos pretos são dados atuais da Figura 3.1.1.1 D (como descrito no texto). A linha pontilhada representa a quantidade de adsorção esperada para a deposição de uma única bicamada de DODAB em cada partícula de sílica.

Página 44

Figura 3.2.1 - Efeito da concentração de DODAB no potencial-zeta $(\zeta)$ e diâmetros médios $\left(\mathrm{D}_{\mathrm{Z}}\right)$ da sílica $(0.05$ ou $0.1 \mathrm{mg} / \mathrm{ml})$ em $0(\square), 0.1(\bigcirc), 0.5(\triangle)$, e $1.0 \mathrm{mM}$ de $\mathrm{KCl}(\nabla)$. Paralelamente, a concentração de DODAB foi expressa em função de $R=A_{b} / A_{s}$.

Página 45 
Figura 3.2.2 - Massa sedimentada de sílica em função do tempo após a adição de fragmentos de bicamadas de DODAB à dispersão de sílica para concentrações finais iguais a $0(\square), 0.01$ $(\bigcirc), 0.3(\triangle)$ e $0.6 \mathrm{mM}$ de DODAB $(\nabla)$.

Página 46

Figura 3.2.3 - Fotografias dos tubos de interação com sílica a $2 \mathrm{mg} / \mathrm{ml}$ incubada com fragmentos de bicamadas de $\operatorname{DODAB}\left(2 \mathrm{~h}, 25^{\circ} \mathrm{C}, \mathrm{pH}\right.$ 6.5) ao longo de uma faixa de valores de $\mathrm{R}$ e de concentrações de $\mathrm{KCl}$. Cada valor de $\mathrm{R}$ foi calculado de $0,0.05,0.1,0.2,0.3,0.5$, 0.6 ou $1.0 \mathrm{mM}$ de concentração final de DODAB.

Página 47 


\section{1 - Introdução}

\section{1 - Introdução Geral}

A deposição de bicamadas ou de vesículas de fosfolipídios ou de anfifílicos sintéticos em superfícies sólidas foi inicialmente descrita em alguns estudos de adsorção de lipossomos em argila [Murase \& Gonda, 1982] ou asbestos [Jaurand et al., 1983], ou através de referências incidentais à adsorção de lipossomos em colunas de filtração em gel [Huang, 1969] ou a filtros de membrana [Schullery \& Garzaniti, 1973].

Considerando as características de partícula coloidal apresentadas por vesículas e as propriedades das interfaces sólido-líquido, pode-se antever que a deposição de vesículas anfifílicas carregadas eletricamente seria determinada inicialmente pela interação entre as duplas camadas elétricas associadas às vesículas e à superfície sólida e por uma força eletrodinâmica de dispersão (van der Waals) entre as vesículas e o sólido.

Como as vesículas não são estruturas sempre rígidas, dependendo do tamanho, da natureza química dos monômeros ou composição do meio de preparação elas podem sofrer distorção, agregação, ruptura ou fusão. A deposição de vesículas em superfícies sólidas pode eventualmente originar um ou uma combinação desses processos.

Este projeto tem por objetivo geral continuar a avaliar a adequação de anfifílicos tipo dialquil de cadeia longa, que se agregam em solução aquosa formando bicamadas, para recobrir superfícies de $\mathrm{SiO}_{2}$. A gama de aplicações práticas do conhecimento básico a ser gerado com este projeto é extensa incluindo os usos petroquímicos, farmacotécnicos, no desenvolvimento de novos materiais e em eletrônica de tecnologias de recobrimento por anfifilicos [Klee et al., 1995, Loidl-Stahlhofen et al., 2001, Groves \& Boxer, 2002, Vagin et al., 2002].

A nível celular, os principais componentes estruturais envolvidos em transdução de sinais através da membrana plasmática e em reconhecimento molecular são as proteínas [Gennis, 1989], que podem atuar como ligantes ou receptores moleculares. Estes geralmente possuem elevado peso molecular e são pouco solúveis em água, necessitando de um microambiente hidrofóbico-hidrofílico adequado para adquirir sua conformação funcional. Esse microambiente ideal é oferecido pela bicamada fosfolipídica que compõe a matriz da membrana celular. As duas grandes vantagens destes receptores celulares, do ponto de vista sensorial, são a elevadíssima especificidade e grande sensibilidade com que realizam o reconhecimento biomolecular. 
Diversos grupos de pesquisa atualmente trabalham no desenvolvimento de tecnologias que visam a biofuncionalização de uma superfície através da imobilização de biomoléculas receptoras em associação com bicamadas lipídicas depositadas. Esses receptores podem ser de natureza protéica como canais iônicos [Graneli et al., 2003], peptídeos sinalizadores [Lee et al., 2001] e transportadores de moléculas [Klee et al., 1992, Sugao et al. 1995], ou de natureza não-protéica como moléculas lipídicas modificadas com grupos adicionais [Buranda et al., 2003] ou gangliosídios incorporados à membrana como ilustrado na Figura 1.1.1 [CarmonaRibeiro, 2001].

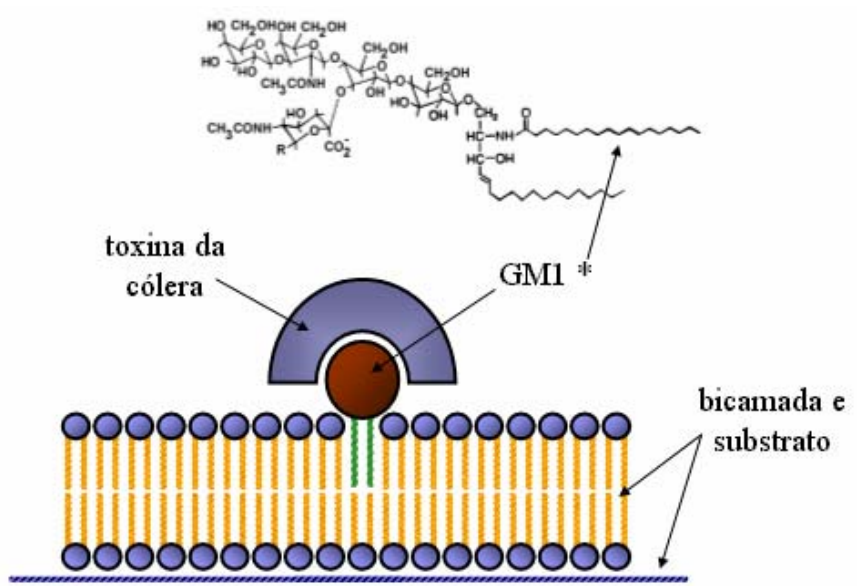

Figura 1.1.1 - Exemplo de biofuncionalização de uma superfície sólida. O receptor utilizado é o monosialogangliosídio GM1, um glicolípide, o qual se insere na bicamada lipídica depositada sobre uma superfície sólida (substrato), e é reconhecido pela toxina da cólera [Carmona-Ribeiro, 2001].

Com isso em mente, conclui-se que o projeto de "kits" de imunoensaios baseado em partículas de sílica teria algumas vantagens sobre aqueles baseados em microesferas de látex (amplamente pesquisados até o momento) como, por exemplo, o menor custo e a maior área superficial. Além disso, a construção de biosensores requer a montagem sobre superfícies semicondutoras de óxido de silício como componente eletrônico. É, portanto, relevante definir um possível uso de partículas esféricas de sílica para amplificar o reconhecimento biomolecular. Assim, o reconhecimento anteriormente amplificado em partículas de poliestireno [Sicchierolli \& Carmona-Ribeiro, 1995; Sicchierolli \& Carmona-Ribeiro, 1996] poderá eventualmente ser amplificado usando sílica recoberta com fosfolipídios ou anfifílicos sintéticos.

Vários tipos de técnicas estão sendo atualmente empregadas para caracterizar a deposição de bicamadas lipídicas modelo em superfícies sólidas. Desde simulações computacionais do comportamento, estrutura e estabilidade de bicamadas anfifílicas [Shillcock \& Lipowsky, 2002] até o acompanhamento em tempo real da deposição de vesículas e da formação de bicamadas em superfícies feito por microscopia de força atômica (AFM) [Cremer \& Boxer, 
1999, Leonenko et al., 2000, Reviakine \& Brisson, 2000, Jass et al., 2000], microbalança de cristal de quartzo (QCM-D) ou ressonância de plasmons de superfície (SPR) [Keller et al., 2000].
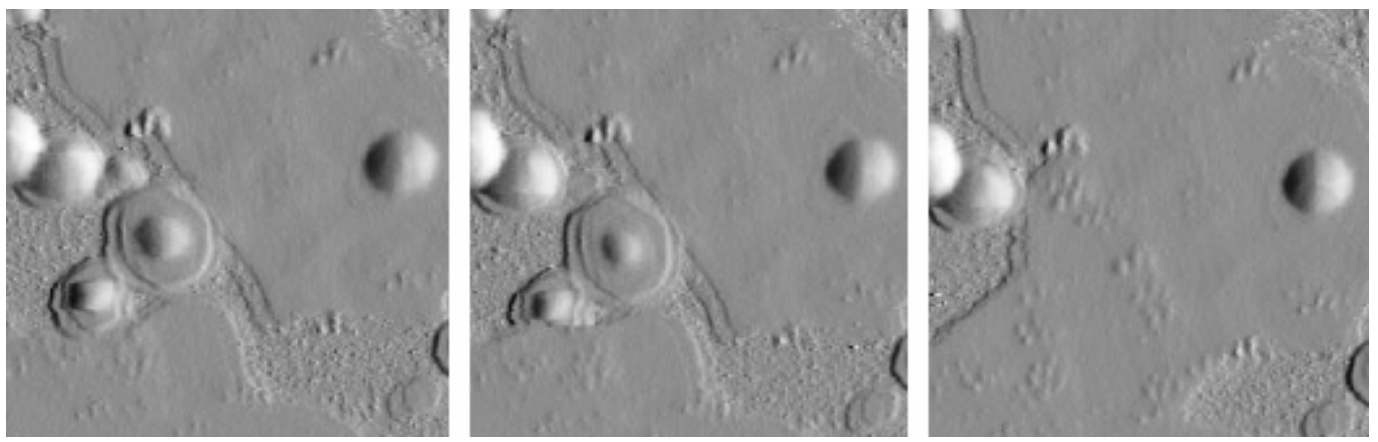

Figura 1.1.2 - Uma seqüência de deposição de vesículas lipídicas esféricas em sílica hidrofílica acompanhada com o uso de um microscópio de força atômica [Jass et al., 2000].

Até o início deste projeto, a deposição de bicamadas lipídicas em superfícies de sílica havia sido estudada somente sob o ponto de vista da variação de $\mathrm{pH}$ do meio, da temperatura e do modo de preparação das dispersões de vesículas [Rapuano, 2000]. Para prosseguir com a caracterização da deposição de bicamadas lipídicas na sílica, foram empregadas neste trabalho técnicas ligadas ao espalhamento quasi-elástico de luz para determinação de distribuições de tamanhos e potenciais elétricos de partículas em dispersões aquosas, assim como cinéticas de sedimentação e isotermas de adsorção, tendo em vista principalmente o efeito da variação da força iônica, $\mathrm{pH}$ e da concentração de anfifílico sobre as propriedades das misturas bicamadaparticulado de sílica. Uma vez otimizadas as condições para deposição de bicamadas, será possível iniciar os estudos de incorporação de receptores e biomoléculas de interesse sobre as bicamadas suportadas em sílica.

\section{2 - Auto-Associação de Moléculas Anfifílicas}

\subsection{1 - Tipos de anfifilicos}

O processo de auto-associação ocorre com estruturas moleculares anfifílicas, ou seja, moléculas que apresentam duas regiões distintas, uma porção hidrofóbica composta por uma ou mais cadeias hidrocarbônicas saturadas ou insaturadas, e uma porção hidrofílica composta por um grupo polar [Kunitake, 1977].

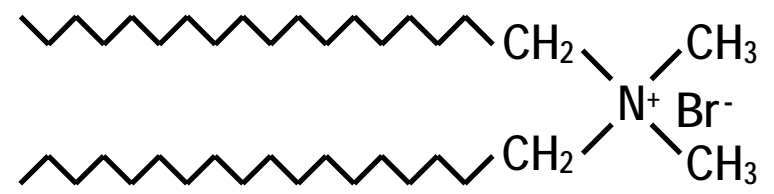

Figura 1.2.1.1 - Estrutura molecular do brometo de dioctadecildimetilamônio (DODAB), um anfifílico sintético catiônico dialquil de cadeia longa, capaz de se auto-associar formando bicamadas. 
Os anfifílicos podem ser classificados como:

- aniônicos: dodecilsulfato de sódio (SDS) $-\mathrm{C}_{12} \mathrm{H}_{25} \mathrm{SO}_{4}{ }^{-} \mathrm{Na}^{+}$

- catiônicos: brometo de dihexadeciltrimetilamônio (HTBA) $-\mathrm{C}_{16} \mathrm{H}_{25} \mathrm{~N}^{+} \mathrm{Me}_{3} \mathrm{Br}^{-}$

- não-iônicos: monoéter de dodecilhexaoxietileno glicol - $\mathrm{C}_{12} \mathrm{H}_{25}\left[\mathrm{OCH}_{2} \mathrm{CH}_{2}\right]_{6} \mathrm{OH}$

- zwiteriônicos: 3-dimetildodecilamino propano sulfonato $-\mathrm{C}_{12} \mathrm{H}_{25} \mathrm{~N}^{+}(\mathrm{Me})_{2}\left(\mathrm{CH}_{2}\right)_{3} \mathrm{SO}_{3}{ }^{-}$

Dentro deste último grupo existe um importante número de materiais de ocorrência natural conhecidos como triacilglicerídeos, por exemplo, a lecitina (ou fosfatidilcolina - PC), que está presente nas membranas de muitas células de animais e cuja estrutura será apresentada posteriormente.

É essencialmente o balanço entre as partes hidrofóbica e hidrofílica da molécula que fornece as propriedades especiais relacionadas à interação das mesmas com superfícies, o que leva a denominar tais sistemas de agentes ativos de superfícies, ou simplesmente surfactantes [Ottewill, 1984].

\subsection{2 - Agregados moleculares e membranas-modelo}

Em função da estrutura peculiar das moléculas anfifílicas, as mesmas quando presentes em solução aquosa sofrem uma auto-organização, podendo dar origem a diferentes estruturas como as micelas, estruturas do tipo bastão, bicamadas, vesículas, fases hexagonais (invertidas ou não), entre outras formas possíveis. Os principais fatores que determinam a autoassociação são as forças de interação de van der Waals, o efeito hidrofóbico, as pontes de hidrogênio, as interações eletrostáticas e o parâmetro de empacotamento crítico ou parâmetro geométrico [Israelachvili, 1992].

Como se pode imaginar, misturas aquosas de anfifílicos são polimórficas. Isso decorre do fato de as moléculas anfifílicas serem associadas fisicamente, e não quimicamente, de modo que a forma e o tamanho do agregado mudam em resposta a variações nas condições da solução. Assim dependem de vários parâmetros como composição e concentração dos anfifílicos, temperatura, força iônica e pH da solução [Gennis, 1989; Evans \& Wennerström, 1994]. São justamente as estruturas formadas a partir da auto-associação dessas moléculas anfifílicas, que são chamadas de sistemas supramoleculares. Esses agregados são denominados colóides de associação, e como exemplo temos: detergentes, membranas celulares, cristais líquidos de "displays", membranas-modelo, certos polímeros, etc...

As dimensões dessas estruturas caem na faixa de partículas coloidais $(1 \mathrm{~nm}-1 \mu \mathrm{m})$. Essas partículas coloidais se formam por agregação de moléculas dispersas em um solvente polar e 
possuem uma grande relação área-volume (por exemplo, uma solução micelar típica, contendo $0.1 \mathrm{~mol} / \mathrm{L}$ tem uma área superficial entre a água e a micela de aproximadamente $4 \mathrm{x}$ $10^{4} \mathrm{~m}^{2}$ por litro de solução). Tais sistemas formam duas fases: a fase dispersa (colóide) e o meio da dispersão (solvente), estando separados por uma interface bem definida [Evans \& Wennerström, 1994]. Daí tem-se que praticamente todas as propriedades físico-químicas destes sistemas são explicadas sob o ponto de vista da Química de Colóides e Superfícies.

Do ponto de vista termodinâmico, a principal força que dirige a formação e estabilização de agregados de anfifílicos hidratados é a chamada interação ou efeito hidrofóbico. Essa força é de natureza entrópica, pois permite uma maior organização das moléculas anfifílicas em forma de agregados, mas às custas de um aumento da entropia da água (solvente), e é resultado de uma coerção ou de uma compressão desfavorável localizada sobre as moléculas de água ao empacotarem em torno de um hidrocarboneto não polar.

Outros fatores, tais como as forças de van der Waals e pontes de hidrogênio têm menor efeito estabilizante sobre o sistema quando comparados à interação hidrofóbica. A interação hidrofóbica é o principal fator de estabilização para virtualmente todas as estruturas biológicas macromoleculares e supramoleculares [Tanford, 1980].

O tamanho e forma do agregado de anfifílico são dependentes dos parâmetros moleculares (volume da porção hidrofóbica da molécula, comprimento de cadeia, e área da cabeça polar) e variáveis intensivas (temperatura e força iônica). O modelo de auto-associação de Israelachvili prevê o agregado ótimo para um determinado conjunto de parâmetros moleculares e variáveis intensivas usando um critério de minimização de energia livre para o monômero no agregado [Israelachvili et al., 1977].

Pode-se assumir que a energia livre de auto-associação de surfactantes em soluções diluídas é constituída de três termos [Evans \& Wennerström, 1994]. Uma contribuição

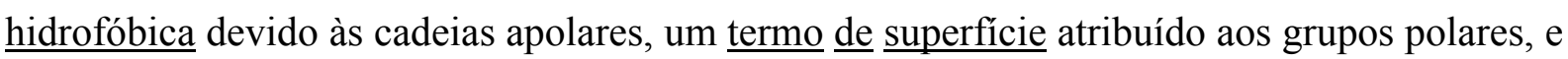
um termo de empacotamento que requer que o interior hidrofóbico do agregado exclua água.

Termos de superfície e empacotamento assumem diferentes formas funcionais para cada agregado geométrico específico. A forma que dá o mínimo de energia livre para um determinado conjunto de condições determina a estrutura ótima do agregado.

Para soluções diluídas em que interações entre agregados não são importantes, pode-se assumir essas concepções convenientemente no parâmetro geométrico $\left(N_{\mathrm{s}}\right)$, que é dado por:

$$
N_{s}=\frac{v}{l a_{0}}
$$


onde, $v$ é o volume da porção hidrofóbica da molécula do surfactante; $l$ é o comprimento da cadeia apolar e $a_{0}$ é a área ótima da cabeça polar. A Tabela 1.2.2.1 ilustra a associação entre o parâmetro geométrico e os agregados supramoleculares formados. À medida que o parâmetro geométrico aumenta, a estrutura supramolecular formada também aumenta.

As interações entre tais unidades estruturais supramoleculares são regidas por forças intermoleculares e de superfície, tais como forças eletrostáticas relativas a dupla camada elétrica, e forças de van der Waals.

Tabela 1.2.2.1 - Agregados supramoleculares de anfifílicos [Israelachvili, 1992].

\begin{tabular}{|c|c|c|c|}
\hline Lipídio & $N_{\mathrm{s}}$ & $\begin{array}{c}\text { Forma do } \\
\text { empacotamento }\end{array}$ & Estrutura formada \\
\hline $\begin{array}{l}\text { Lipídios de cadeia simples (surfactantes) com área da } \\
\text { cabeça polar grande: } \\
\text { SDS em baixa concentração de sal. }\end{array}$ & $<1 / 3$ & Cone & Micela esférica \\
\hline $\begin{array}{l}\text { Lipídios de cadeia simples com área de cabeça polar } \\
\text { pequena: } \\
\text { SDS e CTAB em alta concentração de sal, lipídios não- } \\
\text { iônicos. }\end{array}$ & $1 / 3-1 / 2$ & Tronco de cone & 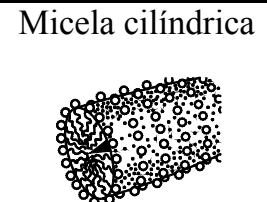 \\
\hline
\end{tabular}

Lipídios de cadeia dupla com área de cabeça polar grande, cadeias fluidas:

Fosfatidilcolina (lecitina), fosfatidilserina, fosfatidilglicerol, fosfatidilinositol, ácido fosfatídico, esfingomielina, diexadecilfosfato, sais de dialquildimetilamônio.

Lipídios de dupla cadeia com área de cabeça polar pequena, lipídios aniônicos em alta concentração salina, cadeias saturadas rígidas:

Fosfatidiletanolamina, fosfatidil serina $\mathrm{I}+\mathrm{Ca}^{2+}$.

$$
1 / 2-1
$$

Tronco de cone

Bicamadas flexíveis, vesículas

Lipídio de dupla cadeia com área de cabeça polar pequena, lipídios não iônicos, cadeias poli (cis) insaturadas:

Fosfatidiletanolamina insaturada, cardiolipina $+\mathrm{Ca}^{2+}$, ácido fosfatídico $+\mathrm{Ca}^{2+}$, colesterol.

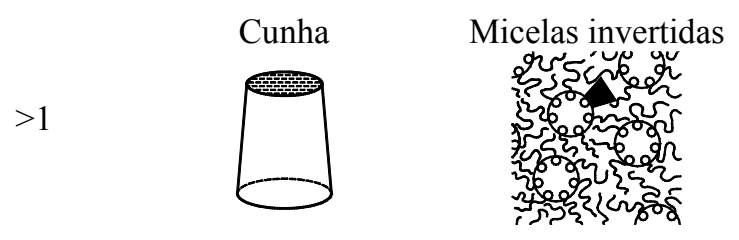

Agregados supramoleculares em forma de bicamadas fechadas (vesículas) possuem uma temperatura de transição de fase $\left(\mathrm{T}_{\mathrm{c}}\right)$, abaixo da qual encontram-se na fase gel, que se caracteriza por uma maior rigidez das cadeias hidrocarbônicas, e acima da qual as cadeias estão mais fluídas, com maior liberdade rotacional e menor densidade de empacotamento, estando a bicamada na fase líquido-cristalina. A transição de fase, observada tanto em membranas-modelo quanto em algumas membranas naturais, depende da carga dos lipídios, 
da composição molecular da membrana, do número de duplas ligações nas cadeias hidrocarbônicas e da incorporação de outras moléculas na estrutura [Bangham et al., 1967, Eibl \& Blume, 1979, Blandamer et al., 1995]. Quanto maior a densidade de empacotamento das cadeias hidrocarbônicas na fase gel, maior será a temperatura de transição de fase [Lee, 1977].

\subsection{3 - Anfifílicos formadores de bicamadas}

Bicamadas planares formadas por moléculas de anfifílicos têm uma posição central no estudo de auto-organização, apresentando papel crucial em processos biológicos e industriais [Evans \& Wennerström, 1994]. Todas as membranas lipídicas dividem algumas propriedades fundamentais em comum. Elas são todas impermeáveis à maioria dos solventes polares ou carregados; têm de 5 a $8 \mathrm{~nm}(50$ a $80 \AA$ ) de espessura e possuem uma estrutura transversal trilamelar. Em condições normais são fluídas porque a maioria das interações entre seus componentes são não covalentes, permitindo que lipídios individuais se movam livremente ao longo do plano da membrana.

Lipídios que formam bicamadas são aqueles que não podem empacotar em estruturas micelares, devido à sua cadeia hidrocarbônica muito volumosa para se ajustar em agregados micelares, enquanto mantêm uma área superficial ótima. Para lipídios formadores de bicamadas, o valor de $v / a_{0} l$ deve ser próximo de 1, e para que isso ocorra é necessário que a área do grupo polar, $a_{0}$, e o comprimento da cadeia hidrocarbônica, $l$, sejam iguais aos valores dos lipídios formadores de micela, e o volume da cadeia hidrocarbônica, $v$, deve ser cerca de duas vezes aquele dos lipídios formadores de micela (para que $v / a_{0} l$ esteja entre $1 / 3$ e 1/2). Por essa razão, lipídios com duas cadeias são prováveis formadores de bicamadas, e de fato a maioria deles forma bicamadas. Por exemplo, lisolecitinas formam micelas pequenas, mas não esféricas, enquanto lecitinas com duas cadeias formam bicamadas.

A duplicação da cadeia também afeta outras propriedades do agregado, tanto estáticas como dinâmicas. Primeiro, aumenta a hidrofobicidade do lipídio, que diminui drasticamente sua concentração micelar crítica (CMC). A CMC de lipídios formadores de micelas está por volta de $10^{-2}$ a $10^{-5}$ enquanto a de lipídios formadores de bicamadas está entre $10^{-6}$ e $10^{-10} \mathrm{M}$. Segundo, aumenta o tempo de residência, $\tau_{R}$, das moléculas dentro do agregado. Para lipídios formadores de micelas, o tempo de residência é aproximadamente $10^{-4} \mathrm{~s}$, enquanto que para lipídios formadores de bicamadas este tempo é de aproximadamente $10^{4} \mathrm{~s}$ [Israelachvili, 1992]. 
Em uma situação ideal, a bicamada se estenderia indefinidamente na direção lateral. Na realidade, amostras finitas, como fragmentos de membrana, mostram defeitos hidrofóbicos nas bordas, e bicamadas tendem a fechar sobre si mesmas, formando estruturas conhecidas como lipossomos [Evans \& Wennerström, 1994].

Vesículas são bicamadas fechadas que delimitam um compartimento aquoso interno e outro externo. São úteis como modelos de membrana. As vesículas, em sua maioria, são termodinamicamente instáveis e as propriedades físicas e funcionais das dispersões destas dependem do método de preparação [Evans \& Wennerström, 1994]. Como exemplos temos:

- sonicação em banho, que forma vesículas multilamelares [Kunitake et al., 1977];

- sonicação por tip, que forma vesículas unilamelares pequenas e/ou fragmentos de membranas [Mortara et al., 1978, Kano et al., 1979, Pansu et al., 1990, CarmonaRibeiro et al., 1991];

- vaporização clorofórmica, que gera vesículas unilamelares grandes [Carmona-Ribeiro \& Chaimovich, 1983, Carmona-Ribeiro et al., 1984];

- injeção etanólica seguida de diálise para eliminação do etanol, que forma vesículas unilamelares pequenas [Batzri \& Korn, 1973];

- injeção etérea, que forma vesículas unilamelares grandes [Deamer \& Bangham, 1976].

O volume capturado por uma vesícula é definido como o volume englobado por mol de anfifílico expresso em litros por mol $(\mathrm{L} / \mathrm{mol})$. Esse parâmetro cresce com o diâmetro da vesícula [Carmona-Ribeiro, 1992a]. O tamanho das vesículas pode ser determinado por microscopia eletrônica ou por espectroscopia de correlação de fótons. Depois de sonicadas (15 minutos para o DODAB) as dispersões são compostas de agregados não esféricos de cerca de 60 a $85 \mathrm{~nm}$ de raio hidrodinâmico. A relação entre o raio hidrodinâmico e o raio de uma esfera com o peso molecular de uma vesícula sonicada está perto de 3 , indicando um pronunciado desvio da forma esférica [Carmona-Ribeiro, 1992b].

Em pesquisa e aplicações de lipossomos o termo estabilidade é usado vagamente e não é freqüentemente bem definido. A definição geral de estabilidade contém vários aspectos que podem ser definidos separadamente, mas freqüentemente agem sinergicamente. A estabilidade física é o aspecto que envolve preservação da estrutura e volume interno do lipossomo, de seu tamanho e forma. Tanto a preservação do tamanho, quanto a encapsulação depende das propriedades mecânicas da bicamada e termodinâmicas dos sistemas. Vesículas são termodinamicamente instáveis porque a membrana é simetricamente curvada, e a baixa energia de conformação das membranas é, em geral, planar [Lasic, 1994]. 
Os mecanismos de degradação de lipídios mais comuns são a oxidação e a hidrólise. Em geral, a cabeça polar é muito mais estável que a cadeia hidrocarbônica. As cadeias hidrocarbônicas insaturadas são objetos de oxidação, em uma reação radicular que em último caso resulta na quebra das cadeias ou, em caso de duplas ligações adjacentes, na formação de peróxidos cíclicos [Lasic, 1994].

Agregação é o primeiro passo na fusão de vesículas entre si e depende da estabilidade termodinâmica da amostra e da presença de substâncias fusogênicas. Fusão é praticamente um processo irreversível enquanto agregação pode ser reversível. Predominantemente, densidade superficial de carga, potencial zeta, distribuição de tamanho e homogeneidade, assim como força iônica e pH do meio determinam a estabilidade coloidal in vitro [Lasic, 1994].

Uma das estratégias deste projeto foi a eliminação dos processos de agregação, ruptura, fusão ou distorção que freqüentemente acompanham a adsorção de bicamadas lipídicas vindas de vesículas sobre uma superfície sólida. Para isso foram empregados pequenos fragmentos abertos de bicamadas lipídicas ao invés de vesículas esféricas fechadas, obtidos por sonicação do DODAB em água [Mortara et al., 1978, Kano et al., 1979, Pansu et al., 1990, CarmonaRibeiro et al., 1991, Hammarström et al., 1995]. Esses fragmentos, assim como as vesículas que os originaram, estão eletrostaticamente estáveis em solução.

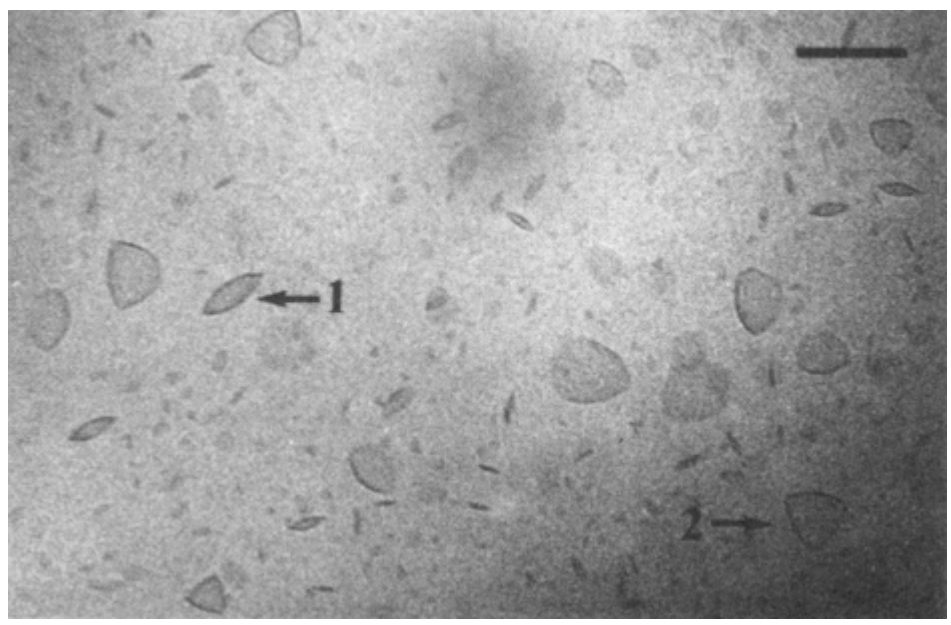

Figura 1.2.3.1 - Crio-TEM (microscopia eletrônica de transmissão) de fragmentos de DODAB obtidos por sonicação. Somente fragmentos de bicamadas de DODAB são encontrados em solução. A barra no lado direito superior da imagem representa $100 \mathrm{~nm}$ de tamanho [Andersson et al., 1995].

\section{3 - Superfícies de $\mathrm{SiO}_{2}$}

O dióxido de silício ou simplesmente óxido de silício $\left(\mathrm{SiO}_{2}\right)$ pode se apresentar tanto no estado cristalino quanto no estado amorfo. No estado cristalino ele ocorre em diferentes formas, mas todas possuem átomos de silício ligados cada um a quatro átomos de oxigênio por meio de uma ligação simples Si-O formando uma estrutura tetraédrica com o átomo de 
silício no centro e os átomos de oxigênio nas pontas do tetraedro. A estrutura tridimensional resultante desse tipo de ligação forma uma rede cristalina estável e não volátil.

De todas as ligações que o silício forma, a ligação Si-O tem uma energia de ligação maior que qualquer outra, com exceção da ligação Si-F. Não é surpreendente então que a química do silício seja dominada por compostos contendo ligações $\mathrm{Si}-\mathrm{O}$, e que o $\mathrm{SiO}_{2}$ seja uma substância quimicamente estável. O óxido de silício constitui aproximadamente $55 \%$ da superfície terrestre e é encontrado em todas as plantas e animais. Ele ocorre em muitas formas na natureza, dentre elas estão a areia, o sílex (pedra de isqueiro), ágata, jaspe, ônix e quartzo [Mortimer, 1971].

Os particulados de sílica possuem grande área específica, sendo que suas propriedades dependem da química de superfície de sua fase sólida. São usados como catalisadores, para processamento mineral, como cerâmicas e adsorventes, e ainda, para fabricação de agentes espessantes em sistemas orgânicos, como tintas, elastômeros, e graxas lubrificantes.

Dois grupos funcionais podem ser encontrados em superfícies de sílica: os silanóis e os siloxanos. Um caráter hidrofílico deve ser atribuído aos grupos silanóis, isto é, esses grupos atraem água e são responsáveis pela alta molhabilidade característica da sílica hidrofílica pela água. Em contraste, os grupos siloxanos são quimicamente inertes.
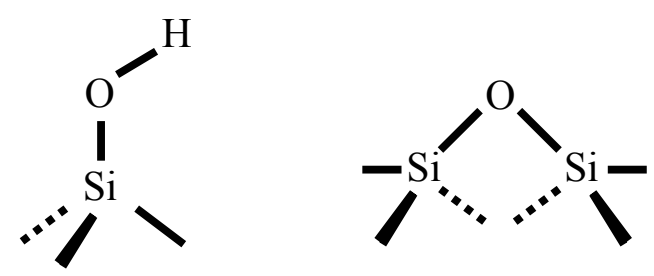

Figura 1.3.1 - Silanol e siloxano, principais grupos encontrados na superfície de $\mathrm{SiO}_{2}$

\subsection{1 - Particulados}

Particulados de sílica podem ser obtidos por diversos modos, entre eles estão:

- Arco sílica - a sílica é produzida por redução da areia de quartzo com coque em um forno arco elétrico e subseqüente oxidação do $\mathrm{SiO}$ formado;

- Processo de plasma - a sílica é formada por meio de gases ionizados;

- Sílica precipitada - sílica que é formada durante a conversão de vidro de silício com ácido sulfúrico;

- AEROSIL - a sílica é produzida por processos de hidrólise em altas temperaturas.

Os dois primeiros métodos de preparação não têm importância técnica, quando comparados com os dois outros métodos [DEGUSSA, 1993]. 
O processo AEROSIL, isto é, a síntese industrial em larga escala de AEROSIL, pode ser descrito como uma hidrólise em chama contínua de tetracloreto de silício $\left(\mathrm{SiCl}_{4}\right)$. Durante esse processo, $\mathrm{SiCl}_{4}$ é convertido à fase gasosa em temperaturas por volta de $1000{ }^{\circ} \mathrm{C}$ e então reage espontaneamente e quantitativamente em uma chama de oxigênio e hidrogênio, formando água intermediariamente e produzindo o dióxido de silício na forma de um fino particulado branco. O único subproduto é cloreto de hidrogênio gasoso que é separado do material AEROSIL sólido:

$$
2 \mathrm{H}_{2}+\mathrm{O}_{2}+\mathrm{SiCl}_{4} \rightarrow \mathrm{SiO}_{2}+4 \mathrm{HCl}
$$

Variando a concentração dos reagentes, a temperatura da chama, e o tempo de residência da sílica na câmara de combustão, é possível variar o tamanho das partículas, a distribuição de tamanho das partículas, a área superficial específica, e as propriedades das superfícies de sílica dentro de limites amplos.

Sílica pirogênica no final do processo possui em sua superfície grupos silanóis (Figura 1.3.1), que lhe conferem características hidrofílicas. A Figura 1.3.1.1 mostra a dissociação destes grupos na superfície da sílica.

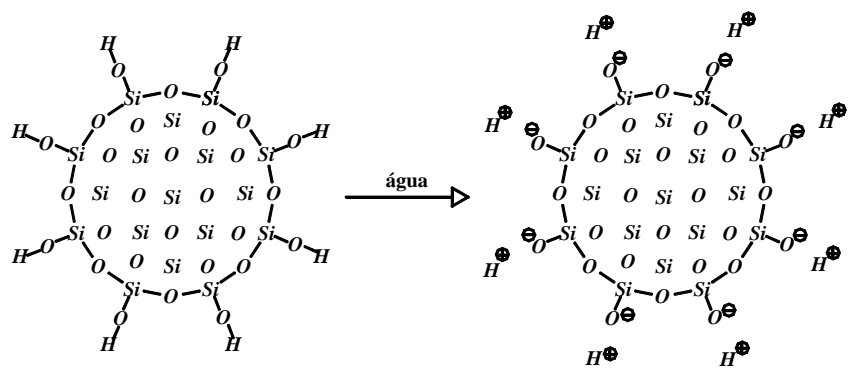

Figura 1.3.1.1 - Dissociação dos grupos silanóis na superfície das partículas AEROSIL.

AEROSIL é um ácido muito fraco (o equilíbrio químico da Figura 1.3.1.1 está deslocado para a esquerda) e apresenta um valor de pKa por volta de 7.2 [Rapuano, 2000]. A densidade superficial de carga, que é uma medida da quantidade de grupos na superfície negativamente carregados, ao redor da partícula de sílica é diretamente proporcional em módulo ao valor do pH e da força iônica do meio aquoso [Tadros \& Lyklema, 1968]. Isso se deve ao fato de que tanto o pH quanto a força iônica do meio favorecem a dissociação dos grupos silanóis da superfície da sílica. A Figura 1.3.1.2 mostra como varia a densidade de carga em função do $\mathrm{pH}$ para $\mathrm{SiO}_{2}$ em quatro concentrações diferentes de $\mathrm{KCl}$.

Como os grupos silanóis podem liberar prótons para o meio aquoso, uma superfície sólida carregada negativamente é criada. Entretanto, já que todo o sistema de dispersão é eletricamente neutro, esse efeito é compensado nos sítios de carga superficial negativa por contra-íons positivos. Enquanto a primeira camada de carga é fixa, o potencial elétrico ao 
redor da partícula na área de uma segunda camada difusa de contra-cargas diminui lentamente. Essa queda da voltagem é conhecida como o potencial-zeta (Figura 1.3.1.3).

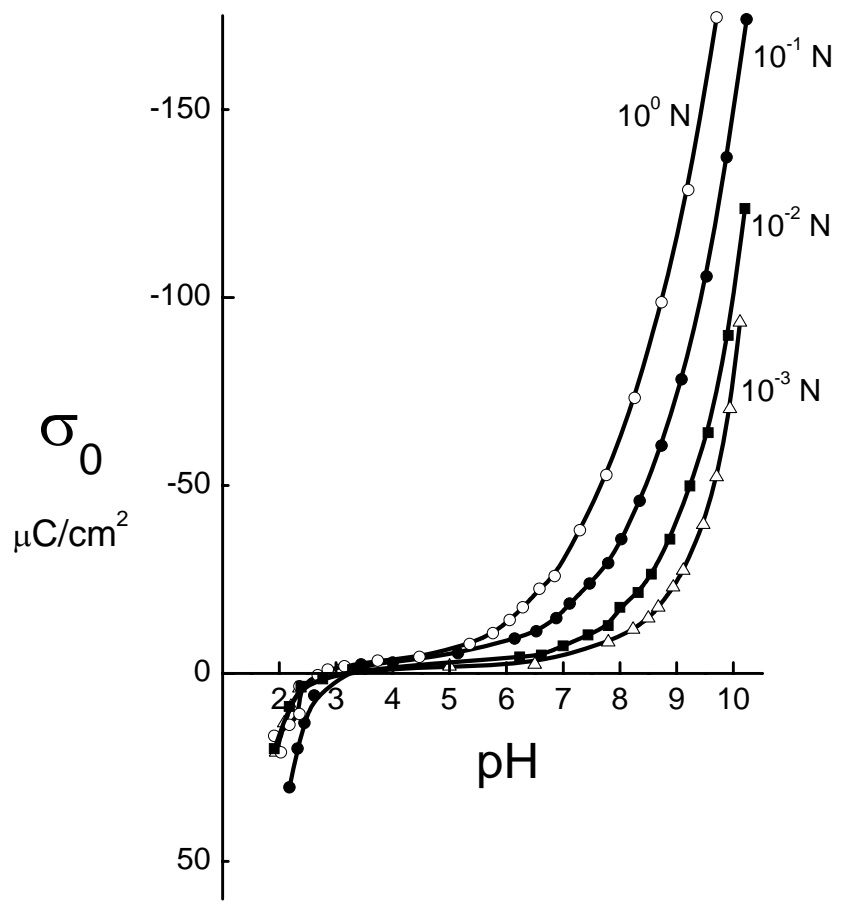

Figura 1.3.1.2 - Densidade superficial de carga em função do $\mathrm{pH}$ para $\mathrm{SiO}_{2}$ em 4 diferentes concentrações de KCl [Tadros \& Lyklema, 1968].

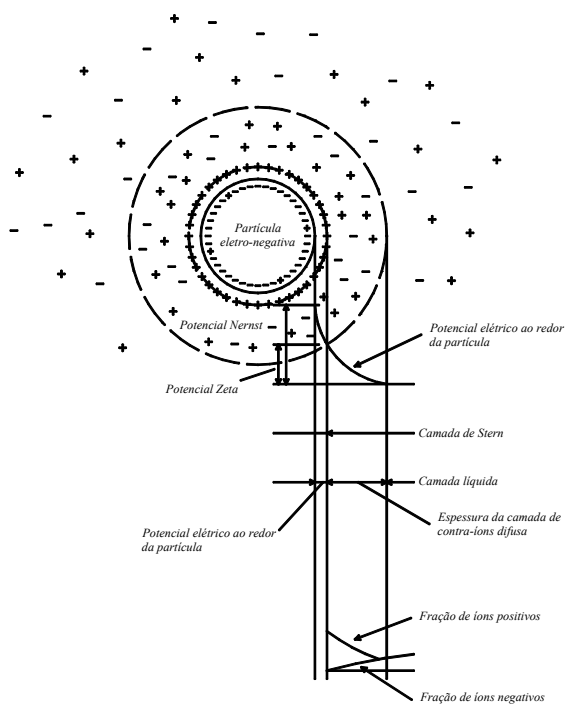

Figura 1.3.1.3 - Dupla-camada elétrica ao redor de uma partícula negativamente carregada, definição de potencial-zeta.

\subsection{2 - AEROSIL OX-50}

A sílica utilizada neste trabalho foi a AEROSIL OX-50, produzida pela DEGUSSA S/A. Esta sílica possui caráter hidrofílico. Com área superficial, obtida pelo método de BET de adsorção de nitrogênio gasoso, de $50 \pm 15 \mathrm{~m}^{2} / \mathrm{g}$, diâmetro médio de partícula de $40 \mathrm{~nm}$ e 
porcentagem de $\mathrm{SiO}_{2}$ superior a 99.8\% [DEGUSSA, 1993]. A Figura 1.3.2.1 mostra a microscopia de transmissão eletrônica (TEM). Este tipo de sílica possui uma baixa superfície específica e ligeira tendência a aglomerar.

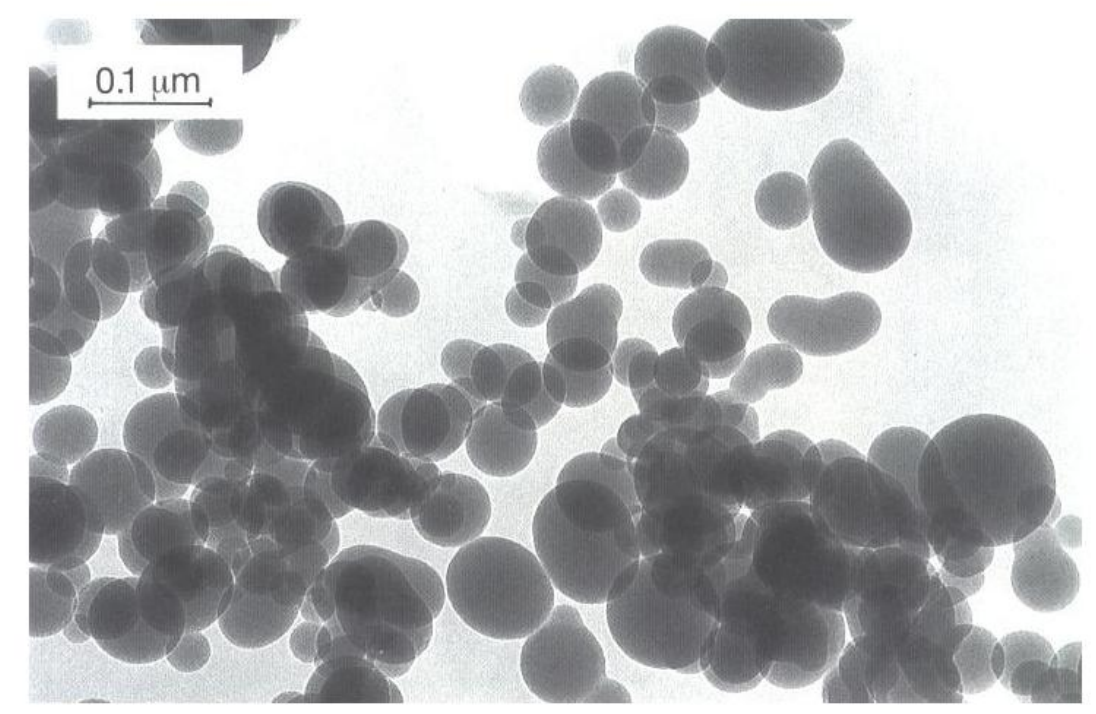

Figura 1.3.2.1 - TEM de AEROSIL OX-50. Como se pode perceber, os diâmetros das partículas se apresentam efetivamente em uma faixa extensa, o que resulta em uma elevada polidispersidade.

Essa aglomeração é resultado principalmente da tendência dos grupos silanóis superficiais de partículas de sílica vizinhas a formarem pontes de hidrogênio entre si mesmas como na Figura 1.3.2.2 A. Essa agregação pode resultar na formação de aglomerados macroscópicos de particulados formando uma estrutura de rede tridimensional temporária, reversível até certo ponto por agitação (Figura 1.3.2.2 B).

A
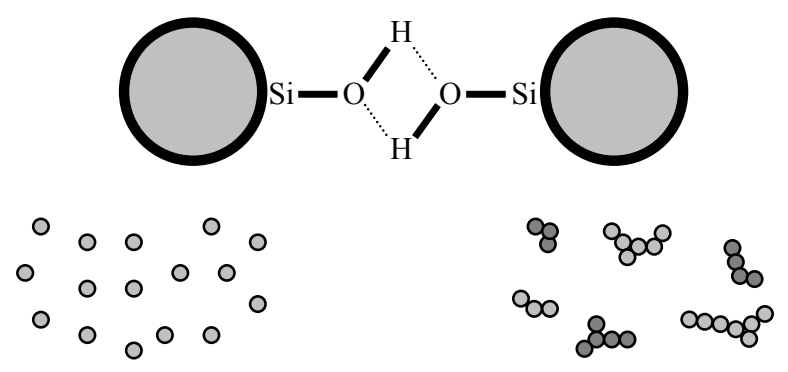

Partículas primárias

Agregados

$\mathrm{B}$

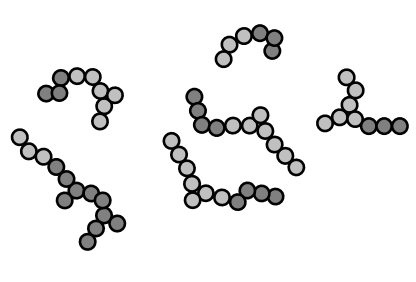

Agregados Aglomerados
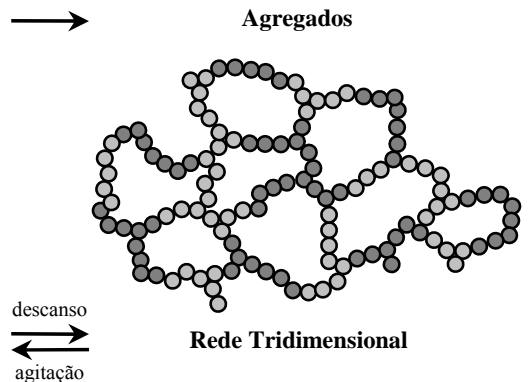

Figura 1.3.2.2 - Representação da formação de pontes de hidrogênio entre partículas (A) e aglomeração dos agregados em uma rede tridimensional macroscópica (B). 


\section{4 - Adsorção de Membranas-Modelo em Superfícies}

\subsection{1 - Aspectos físico-químicos da adsorção em superfícies}

Primeiramente é conveniente fazer algumas definições gerais sobre superfícies e sobre o fenômeno de adsorção.

As superfícies das fases têm um comportamento diferente do que apresenta a parte interior das próprias fases, por causa das rápidas mudanças estruturais que devem ocorrer nas fronteiras das fases e suas vizinhanças. Os arranjos de ligação de equilíbrio são rompidos, nascendo ai uma energia de excesso associada à superfície (isto é, energia de superfície $\gamma$ ), que é medida em energia por unidade de área.

A energia em excesso pode ser tornada mínima se fizermos com que a área superficial seja mínima. A energia de superfície pode ser diminuída pela segregação de vários componentes na direção da superfície ou em direção contrária, em um comportamento conhecido como adsorção. A teoria da adsorção é amplamente empregada em vários sistemas, e estabelece que havendo um contato molecular suficientemente íntimo na interface separando dois meios ou fases, os materiais vão aderir a esta devido a forças intermoleculares e interatômicas.

Essas forças podem ser divididas em duas classes distintas:

\section{a) Adsorção Física ou Fisissorção:}

- Forças entre o adsorbato e adsorvente sem formação de compostos.

- Interações não orientadas e não especificas.

- Envolve baixas energias de interação (300 a 3000 J.mol ${ }^{-1}$ ).

- Facilmente reversível, o material dessorvido é o mesmo que foi adsorvido.

- Exemplo típico: Adsorção de nitrogênio $\left(\mathrm{N}_{2}\right)$ sobre óxido de silício.

\section{b) Adsorção Química ou Quimissorção:}

- Forças de natureza química que levam à formação de compostos.

- Interações de caráter mais específico.

- Altas energias de interação (40000 a $400000 \mathrm{~J} \cdot \mathrm{mol}^{-1}$ )

- Dificilmente reversível, muitas vezes reações químicas levam à dessorção de material diferente do que foi adsorvido.

- A adsorção não mais ocorre quando a superfície está completamente coberta por uma monocamada do material adsorvido.

- Exemplo típico: adsorção de oxigênio $\left(\mathrm{O}_{2}\right)$ sobre carvão.

O fenômeno da adsorção de várias espécies, particularmente os anfifílicos, pode ocorrer em interfaces ar-liquido, liquido-liquido, e sólido-liquido. Para este trabalho irá se considerar 
o caso da adsorção na interface sólido-liquido. Fisicamente, uma interface é caracterizada principalmente pela energia livre interfacial ou tensão, que é resultado da orientação das moléculas que constituem a interface. Estas e outras propriedades interfaciais das membranas podem ser largamente compreendidas com base nos termos físico-químicos que as governam [Wäengnerud \& Jöensson, 1994, Li \& Ruckestein, 1996, Sharma et al., 1996].

Neste trabalho, a formação de bicamadas sobre uma superfície sólida ocorre pela interação de vesículas com a superfície, sendo neste caso uma adsorção física.

\subsection{2 - Isotermas de adsorção}

O contato de uma substância tensoativa diluída em solução aquosa com uma grande superfície adsorvente poderá levar a uma adsorção extensiva com uma redução contínua na concentração da solução. Para se ter uma superfície grande para adsorção, o sólido - que é chamado de adsorvente - deve ser finamente dividido. A partir de dados analíticos que descrevem a mudança de concentração na solução, assim como o conhecimento da quantidade total de sólido da solução equilibrada, é possível determinar a quantidade de soluto adsorvido, que é chamado de adsorbato, por unidade de peso do sólido. Se a área específica do sólido é conhecida, então os resultados podem ser expressos como quantidade adsorvida por unidade de área. Esses estudos são geralmente conduzidos a temperatura constante, e os resultados, que relacionam a quantidade de material adsorvido com a concentração de equilíbrio em solução, definem uma isoterma de adsorção [Hiemenz, 1986].

\subsubsection{1 - Tipos de isotermas}

Isotermas para adsorção de solutos orgânicos são divididas em quatro classes principais, de acordo com a natureza do coeficiente angular da porção inicial da curva.

As principais classes são:

- curvas $\mathrm{S}$, indicativas de orientação vertical de moléculas do adsorbato na superfície;

- curvas L, isotermas normais ou de "Langmuir", usualmente indicativas de adsorbatos "deitados" sobre a superfície, ou às vezes, adsorbatos iônicos orientados verticalmente com atração intermolecular particularmente forte;

- curvas H, (“alta afinidade”) (começando de um valor positivo no eixo de concentração adsorvida sobre o sólido), freqüentemente resultando da adsorção de solutos como micelas iônicas, ou de troca iônica de alta-afinidade com íons de baixa-afinidade;

- curvas C ("partição constante"), curva linear, resultando da adsorção de solutos que adsorvem no sólido mais rapidamente do que o solvente [Giles et al., 1960]. 
Os subgrupos destas classes estão arranjados de acordo com a forma das curvas depois do ponto de origem e da posição do platô [Rapuano, 2000]. Assim, se as moléculas do soluto que estão adsorvidas na nova superfície apresentam baixa atração por mais moléculas, a curva apresenta um longo platô. Se as moléculas que estão adsorvidas na superfície apresentam alta afinidade por mais soluto, a curva cresce continuamente e não apresenta platô (Figura 1.4.2.1.1)

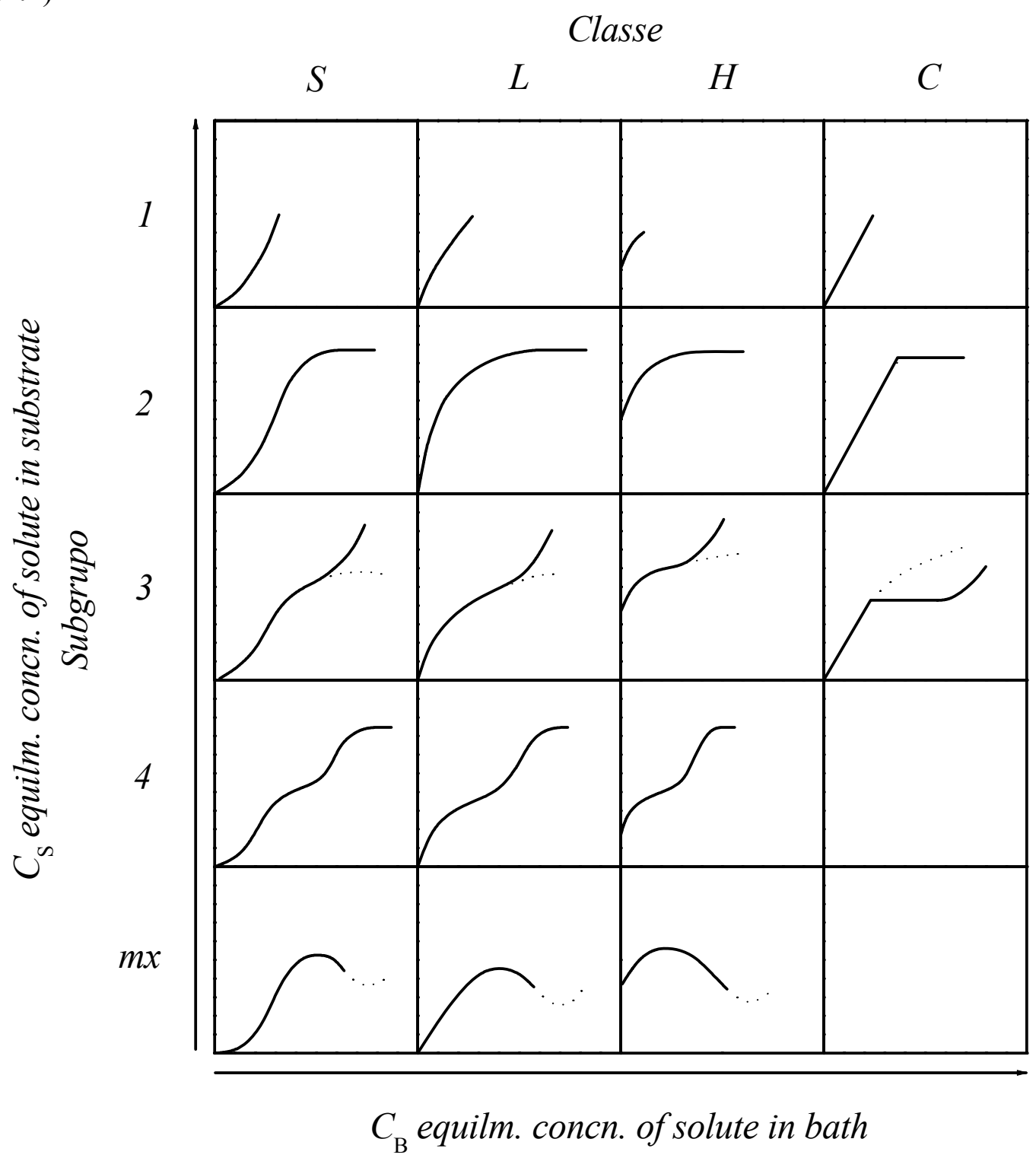

Figura 1.4.2.1.1 - TEM de AEROSIL OX-50. Como se pode perceber, os diâmetros das partículas se apresentam efetivamente em uma faixa extensa, o que resulta em uma elevada polidispersidade.

As curvas L são as mais conhecidas; na verdade a curva L2 ocorre em provavelmente na maioria dos casos de adsorção a partir de soluções diluídas.

A inclinação inicial depende da velocidade de mudança do sítio de adsorção com aumento no soluto adsorvido. Para haver adsorção de uma dada quantidade adicional do soluto, a concentração do soluto deve ser aumentada. Na parte inicial das curvas $\mathrm{S}$, no entanto, a 
condição oposta é aplicada, e quanto mais soluto já está adsorvido, mais fácil serem adsorvidas quantidades adicionais. Isso implica em uma associação lado a lado entre as moléculas adsorvidas ou adsorção cooperativa.

$\mathrm{Na}$ prática, a curva $\mathrm{S}$ usualmente aparece quando três condições são preenchidas: a molécula do soluto (a) é monofuncional, (b) tem moderada atração intermolecular, causando o empacotamento vertical na camada adsorvida e (c) encontra forte competição, pelos sítios do substrato, a partir de moléculas do solvente ou de outras espécies adsorvidas. Essa isoterma aparentemente indica a tendência de moléculas de adsorbatos se associarem, ao invés de se manterem em unidades isoladas.

Nas curvas L, a curvatura inicial mostra que quanto mais sítios são preenchidos torna-se mais difícil a adsorção de moléculas do soluto em novos sítios. Isso implica que as moléculas adsorvidas não estão verticalmente orientadas, ou que não existe uma forte competição do solvente. Os tipos de sistemas que apresentam este tipo de curva de fato preenchem essas condições, possuindo as seguintes características: (i) as moléculas adsorvidas são preferencialmente adsorvidas deitadas; (ii) se adsorvidas verticalmente as moléculas sofrem uma pequena competição pelo solvente. Exemplos de (ii) são: (a) sistemas com solutos e substratos altamente polares, (b) sistemas com substâncias iônicas monofuncionais com atração intermolecular muito forte. É possível que nesses casos (sistemas b), os íons adsorvidos possam se associar em aglomerados muito grandes antes da adsorção acontecer.

As curvas $H$ são um caso especial da curva $L$, em que o soluto tem tão alta afinidade pela superfície, que em soluções diluídas é completamente adsorvido, ou pelo menos, não permanece em quantidades mensuráveis na solução remanescente. A parte inicial da isoterma é vertical. As espécies adsorvidas são freqüentemente unidades grandes como micelas e bicamadas iônicas ou moléculas poliméricas, mas às vezes elas são íons aparentemente simples que trocam com outros íons de afinidade muito menor pela superfície. Para altíssimas afinidades, a curva é uma linha horizontal.

Nas curvas C, os sítios de adsorção mantêm-se constantes em todas as concentrações até a saturação. A curva C é caracterizada por partição constante do soluto entre solução e substrato, diretamente até a adsorção máxima possível, onde há uma mudança abrupta no platô horizontal.

As condições que favorecem o aparecimento de curva C são: (a) um substrato poroso com moléculas flexíveis e regiões com diferentes graus de cristalinidade, e um soluto com (b) mais alta afinidade pelo substrato do que pelo solvente e com (c) melhor poder de penetração, em virtude da condição (b) e da geometria molecular, nas regiões cristalinas do substrato. 
Fundamentalmente, a linearidade mostra que os números de sítios para adsorção mantêmse constantes; isto é, quanto mais soluto é adsorvido, mais sítios devem ser criados. Uma isoterma linear indica que o soluto está adsorvendo em regiões inacessíveis ao solvente, ou seja, há excesso de sítios disponíveis para a adsorção.

Um dos tipos mais comuns é a isoterma de Langmuir, importante por ser facilmente entendida teoricamente, e largamente aplicada aos mais diferentes dados experimentais. Uma das fórmulas deste modelo pode ser expressa por:

$$
x_{s}^{2}=\frac{k a_{2}^{b}}{k a_{2}^{b}+1}
$$

onde $x_{s}^{2}$ é a fração molar do soluto na superfície, $a_{2}^{b}$ é a atividade do soluto na solução, e k é uma constante. Tal isoterma decorre do fato de se considerar a adsorção do soluto segundo a Equação 1.4.2.1.2.

Solvente $_{\text {adsorvido }}+$ Soluto em solução $_{\rightarrow}$ Soluto adsorvido + Solvente em solução

A constante de equilíbrio para essa reação pode ser definida como:

$$
k=\frac{a_{2}^{s} a_{1}^{b}}{a_{1}^{s} a_{2}^{b}}
$$

onde $a$ representa a atividade das espécies e os sobrescritos $s$ e $b$ significam superfície e seio da solução, respectivamente.

Nesta teoria é suposto que uma solução em que ambos solvente (componente 1) e soluto (componente 2) têm moléculas que ocupam a mesma área ao adsorverem na superfície. Assumindo que a solução na superfície bidimensional é ideal, podemos substituir atividade na superfície por fração molar na superfície $x^{s}$ definida como:

$$
k=\frac{x_{2}^{s} a_{1}^{b}}{x_{1}^{s} a_{2}^{b}}
$$

Uma forma equivalente da equação de Langmuir expressa em variáveis ligeiramente diferentes é obtida multiplicando ambos $x_{1}^{s}$ e $x_{2}^{s}$ na Equação 1.4.2.1.4 pela área total da superfície. Como foi postulado que tanto o solvente como o soluto ocupam áreas iguais sobre a superfície, então, $x_{i}^{s} A$ é igual à fração da superfície ocupada pelo componente $i, \theta_{1}$. Desde que $\theta_{1}+\theta_{2}=1$, a relação $\theta_{1} / \theta_{2}$ rearranja da mesma maneira que $x_{2}^{s} / x_{1}^{s}$ para dar:

$$
\theta_{2}=\frac{k a_{2}^{b}}{k a_{2}^{b}+1}
$$


Nesta forma a equação de Langmuir mostra como a fração dos sítios de adsorção da superfície ocupada pelo soluto aumenta com a atividade do soluto em soluções com concentrações crescentes.

A adsorção de DODAB sobre sílica hidrofílica a partir de vesículas pequenas em solução aquosa é geralmente representada por isotermas de adsorção de alta afinidade [Tadros \& Lyklema, 1968, Milonjić, 1987], que neste caso é compatível com a formação de par iônico entre os grupos silanóis dissociados da sílica e os grupos amônio quaternário do DODAB. Em geral este tipo de isoterma é obtido quando o adsorbato tem tão alta afinidade que, em soluções diluídas, é completamente adsorvido, ou pelo menos quantidades remanescentes na solução não são mensuráveis. Assim, a parte inicial de todas estas isotermas é vertical. Contudo, com o aumento da concentração de DODAB, a quantidade adsorvida diminui em todos os casos. Este efeito resulta da associação do adsorbato em solução [Giles et al., 1960], isto é, aumentando a concentração de DODAB a interação vesícula/vesícula em solução aumenta mais rapidamente que a atração pela sílica. Isto ocorre, pois vesículas de DODAB sonicadas interagem entre si devido à sua preferência por menor curvatura, presença de fragmentos de bicamadas, tendência a formar lipossomos multilamelares, tendência a fundir, etc. [Carmona-Ribeiro, 1992a]. 


\section{2 - Materiais e Métodos}

\section{1 - Reagentes e materiais}

Água Deionizada (Milli-Q) foi utilizada no preparo de todas as soluções utilizadas neste trabalho.

Brometo de dioctadecildimetilamônio $(99.9 \%$ puro) - DODAB - obtido da Sigma Chemical Company e utilizado sem purificação prévia.

Ácido Clorídrico p.a. - $\mathrm{HCl}$ - obtido da MERCK e utilizado para ajuste de $\mathrm{pH}$ e padronização de titulantes.

Hidróxido de sódio p.a. $-\mathrm{NaOH}$ - obtido da MERCK e utilizado para ajuste de $\mathrm{pH}$.

Cloreto de sódio p.a. - $\mathrm{NaCl}$ - obtido da MERCK e utilizado para preparação de soluções salinas de $1 \mathrm{M}$.

Ácido nítrico p.a. $(65 \%)-\mathrm{HNO}_{3}$ - obtido da MERCK e utilizado para preparação de solução titulante de $\mathrm{Hg}\left(\mathrm{NO}_{3}\right)_{2}$

Cloreto de potássio p.a. - $\mathrm{KCl}$ - obtido da MERCK e utilizado para a preparação de soluções salinas de concentração $0.1 \mathrm{mM}, 1 \mathrm{mM}$ e $10 \mathrm{mM}$.

Tris(hidroximetil)aminometano hidrocloreto (> 99\% puro) - Tris- $\mathrm{HCl}$ - foi obtido da Sigma Chemical Company e utilizado para preparação de tampões de concentração $10 \mathrm{mM} \mathrm{e}$ cujo $\mathrm{pH}$ foi ajustado com $\mathrm{NaOH} 1 \mathrm{~mol} / \mathrm{L}$ para 7.4.

Etanol (86\% puro) $-\mathrm{C}_{2} \mathrm{H}_{5} \mathrm{OH}$ - obtido da MERCK.

Nitrato de mercúrio p.a. - $\mathrm{Hg}\left(\mathrm{NO}_{3}\right)_{2}$ - obtido da MERCK foi utilizado para a preparação de solução titulante de $8.72 \mathrm{mM}$.

1,5-Difenilcarbazona $-\mathrm{C}_{13} \mathrm{H}_{12} \mathrm{~N}_{4} \mathrm{O}$ - obtido da MERCK foi utilizado como indicador sensível ao mercúrio, com o qual forma complexo de cor azulada, nas reações de titulação.

Orange $\mathrm{G}$ (95\% puro) $-\mathrm{C}_{16} \mathrm{H}_{10} \mathrm{~N}_{2} \mathrm{O}_{7} \mathrm{~S}_{2} \mathrm{Na}_{2}$ - obtido da Aldrich Chemical Company.

Brij $35-\mathrm{C}_{12} \mathrm{E}_{23}-$ (Lauril Eter) p.a. obtido da Aldrich-Chemie.

Partículas de silica hidrofilica - AEROSIL OX-50 - foram obtidas da Degussa S/A. A área superficial específica destas partículas foi determinada por titulação potenciométrica em meio de $20 \%$ de $\mathrm{NaCl}$ com NaOH 0,1 M [Sears Jr., 1956] e por adsorção de $\mathrm{N}_{2}$ (BET) [Hiemenz, 1986, Brunauer et al., 1938, Rapuano, 2000]. As partículas utilizadas possuem área superficial específica de $25.98 \mathrm{~m}^{2} / \mathrm{g}$ (BET), em bom acordo com a área superficial específica obtida por titulação potenciométrica, que foi $27 \mathrm{~m}^{2} / \mathrm{g}$. A área superficial específica fornecida pela Degussa S/A para estas partículas é de $50 \pm 15 \mathrm{~m}^{2} / \mathrm{g}$. Esta grande discrepância entre os valores de área superficial específica obtidos por BET e por titulação e o valor de área 
superficial específica fornecida pela Degussa S/A mostra a tendência dessas partículas agregarem. O diâmetro médio das partículas primárias (não agregadas) é de $40 \mathrm{~nm}$ segundo dados fornecidos pela Degussa S/A.

\section{2 - Equipamentos utilizados *}

Dinamômetro (BYK - Labotron, Germany). Projetado para ser utilizado como tensiômetro, balança de sedimentação e densímetro, o equipamento foi utilizado para a medição de cinéticas de sedimentação e para medidas de tensão superficial.

Espectrofotômetro (Model Spectrascan 2800 CIBA-CORNING). Aparelho equipado com sistema ótico de feixe duplo de luz monocromática, com fontes de luz à base de deutério $(200 \mathrm{~nm}$ a $350 \mathrm{~nm})$ e iodeto de tungstênio $(350 \mathrm{~nm}$ a $1100 \mathrm{~nm})$ com $\pm 0.5 \mathrm{~nm}$ de precisão no comprimento de onda medido e precisão fotométrica de \pm 0.005 Abs na escala de 0 a 1 Abs medidos. A reprodutibilidade fotométrica é de \pm 0.001 Abs na escala de 0 a 0.5 Abs medidos; e de \pm 0.002 Abs na escala de 0.5 a 1.0 Abs medidos.

Sonicador (Lab-Line Ultra Tip Labsonic System - Modelo 150 com tip de titânio). Aparelho desenvolvido para romper, através da emissão de ondas sonoras de um ultra-tip, as paredes ou membranas celulares de células em experimentos microbiológicos. Aqui ele foi utilizado para formar vesículas e fragmentos de vesículas de anfifílicos pelo mesmo princípio de ultra-som.

ZetaPlus Zeta-Potential Analyzer (Brookhaven Instruments Corporation, NY). Instrumento desenvolvido para o uso com suspensões de partículas ou soluções de macromoléculas. Tamanhos de $10 \mathrm{~nm}$ a $30 \mu \mathrm{m}$ (dependendo da densidade da partícula) e potenciais zeta de $-150 \mathrm{a}+150 \mathrm{mV}$ podem ser medidos com uma precisão e reproducibilidade de $\pm 2 \%$ em ambos os casos. A fonte de luz é um laser de estado sólido de $30 \mathrm{~mW}$. Os resultados são exibidos em valores modais ou distribuição de tamanho em uma interface Windows de fácil operabilidade.

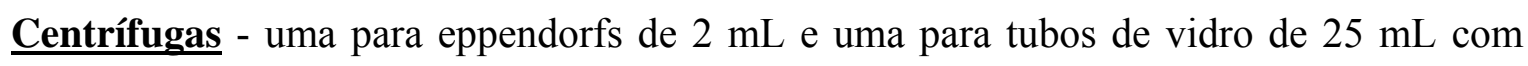
velocidades de rotação de 0 a 14,000 rpm e 0 a 20,000 rpm respectivamente e temperaturas de -9 a $40{ }^{\circ} \mathrm{C}$ e -10 a $40{ }^{\circ} \mathrm{C}$ respectivamente.

Balança Analítica - com precisão de $\pm 0.0001 \mathrm{~g}$

pH metro (Corning $\mathrm{pH}$ meter 430). Precisão de $\mathrm{pH} \pm 0.01 ; \pm 1 \mathrm{mV} ; \pm 1{ }^{\circ} \mathrm{C}$.

Câmera digital (HP Photosmart 215).

(* informações obtidas dos manuais de usuário de cada aparelho) 


\section{3 - Preparação das dispersões.}

\subsection{1 - Obtenção de anfifílicos e preparação de vesículas}

A massa de DODAB calculada para uma concentração final desejada foi pesada em um béquer de $50 \mathrm{~mL}$, e sobre ela foram adicionados $50 \mathrm{~mL}$ de água deionizada, ou de solução aquosa de $\mathrm{KCl}$, ou de solução aquosa de tampão Tris $10 \mathrm{mM}$ dependendo das condições finais desejadas. Essa mistura foi então submetida ao ultra-som do sonicador por 15 minutos a uma potência média de $85 \mathrm{~W}$. Terminada a sonicação, uma pequena quantidade de água deionizada é adicionada para compensar possíveis perdas por evaporação durante o processo. A amostra é então centrifugada em um tubo de vidro COREX para centrífuga de $25 \mathrm{~mL}$ por 1 hora à rotação de 14,000 rpm, com o propósito de eliminar as partículas residuais de titânio e eventuais vesículas multilamelares que podem ter se formado no processo.

\subsection{2 - Sílica coloidal}

A massa de sílica calculada para uma concentração final desejada foi pesada em um béquer de $50 \mathrm{~mL}$, e sobre ela foram adicionados $50 \mathrm{~mL}$ de água deionizada, ou de solução aquosa de tampão Tris $10 \mathrm{mM}$ dependendo das condições finais desejadas. Essa mistura foi então submetida ao ultra-som do sonicador por 15 minutos a uma potência média de 85 WATTS. Terminada a sonicação, uma pequena quantidade de água deionizada é adicionada para compensar possíveis perdas por evaporação durante o processo.

As partículas de titânio depositadas não podem ser removidas por centrifugação devido a pouca diferença de tamanho entre elas e as partículas de sílica. Elas devem ser removidas da solução manualmente com o uso de uma pipeta de vidro após decantação.

\section{4 - Métodos analíticos para a determinação da concentração de DODAB}

\subsection{1 - Determinação da concentração por microtitulação}

Este método é empregado quando a dispersão de DODAB está em água, e consiste numa microtitulação da solução em estudo com o titulante nitrato de mercúrio (II) $\left[\mathrm{Hg}\left(\mathrm{NO}_{3}\right)_{2}\right] 0.872$ $\mathrm{mM}$ utilizando-se como indicador a difenilcarbazona [Schales e Schales, 1941], tendo-se o cuidado de adicionar etanol absoluto à dispersão de vesículas para garantir o seu rompimento e solubilização da bicamada. 


\subsection{2 - Determinação da concentração por colorimetria}

Este método é empregado quando o DODAB está disperso em solução aquosa salina de $\mathrm{KCl}$ ou tampão TRIS [Stelmo et al., 1987]. O método baseia-se na formação de complexos estáveis entre o corante Orange $\mathrm{G}$ e os íons $\operatorname{DODA}^{+}$que podem ser solubilizados em soluções aquosas contendo micelas neutras de Brij 35. As variações na absorbância devido à formação do complexo (Orange G)/DODAB ${ }^{+}$na presença de Brij 35 foram usadas por Stelmo et al. para desenvolver este método para análise quantitativa de anfifílico de cadeia longa de alquilamônios, baseado na diminuição de leituras de absorbância do complexo colorido ao interagir com as micelas de Brij. A solução de Brij foi preparada da seguinte maneira:

- 0.0271 g de Orange G;

- 0.0718 g de Brij 35;

- $5.844 \mathrm{~g}$ de NaCl;

- água q.s.p. 1 litro; agitação até solubilização total.

Este método consiste na obtenção da curva padrão de DODAB através de uma dispersão já padronizada do mesmo anfifílico, por exemplo, dispersão de DODAB $2 \mathrm{mM}$. A partir desta dispersão, foram tomadas alíquotas de 0 a $100 \mu \mathrm{L}$, variando de $10 \mu \mathrm{L}$ cada ponto. Da amostra a ser analisada, foram tomadas três alíquotas de $100 \mu \mathrm{L}$. Foram adicionados $2 \mathrm{~mL}$ de solução de Brij em cada alíquota de padrão ou amostra e foram deixados em banho-maria a $50{ }^{\circ} \mathrm{C}$ por 30 minutos. Depois foram transferidos para um banho-maria a $37^{\circ} \mathrm{C}$ e após a estabilização da temperatura, os padrões e amostras que interagiram com a solução de Brij foram submetidos às leituras de absorbância a $480 \mathrm{~nm}$ no espectrofotômetro com o controle de temperatura a 37 ${ }^{\circ} \mathrm{C}$ para este experimento. Como branco foi utilizada solução de $\mathrm{NaCl}$ 0.1 M. A Tabela 2.4.2.1 segue com um exemplo de doseamento de DODAB pelo método de Brij.

Tabela 2.4.2.1 - Leituras e correção de leituras de absorbância pelo método do Brij para curva padrão de DODAB. Curva padrão.

\begin{tabular}{cccc} 
Abs $(\mathrm{br})=$ & 1,054 & $\mathrm{Abs}$ & \\
\hline Vdoda $(\mu \mathrm{L})$ & $\begin{array}{c}\text { Abs } \\
(480 \mathrm{~nm})\end{array}$ & $\begin{array}{c}\text { Abs } \\
(\text { corr. })\end{array}$ & $\begin{array}{c}\text { CDodAB } \\
\text { padrão } \\
(\mathrm{mM})\end{array}$ \\
\hline 10 & 1,024 & 1,029 & 0,0100 \\
20 & 0,989 & 0,999 & 0,0198 \\
40 & 0,920 & 0,938 & 0,0392 \\
60 & 0,859 & 0,885 & 0,0583 \\
80 & 0,798 & 0,830 & 0,0769 \\
100 & 0,759 & 0,797 & 0,0952 \\
\hline
\end{tabular}

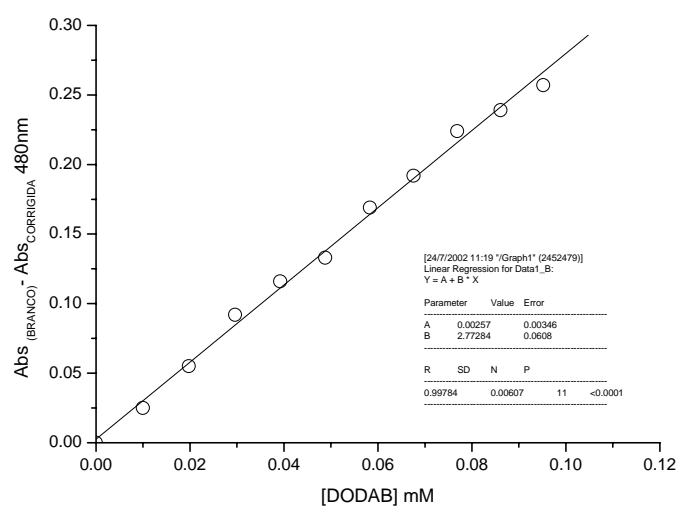


Pela interpolação na curva padrão (Tabela 2.4.2.1) ou pela sua equação da reta foram retirados os parâmetros A e B (Tabela 2.4.2.1), com os quais foi obtida a concentração em cada tubo (C CoDAB $_{\text {tubo) }}$ (Tabela 2.4.2.2).

Tabela 2.4.2.2 - Doseamento da dispersão de vesículas de DODAB obtidas por aquecimento em presença de $\mathrm{KCl} 1 \mathrm{mM}$. Leituras e correção de leituras de absorbâncias pelo método de Brij.

\begin{tabular}{|c|c|c|c|c|c|c|}
\hline $\begin{array}{l}\text { V DODAB } \\
(\mu 1)\end{array}$ & $\begin{array}{c}\text { Abs } \\
(480 n m)\end{array}$ & $\begin{array}{c}\text { Abs } \\
\text { (corr.) }\end{array}$ & $\begin{array}{c}\Delta \mathrm{Abs} \\
\text { (br-cor) }\end{array}$ & $\begin{array}{c}\text { Coodab tubo } \\
(\mathrm{mM})\end{array}$ & $\begin{array}{c}\text { CDODAB } \\
\text { sobr. } \\
(\mathrm{mM})\end{array}$ & $\begin{array}{l}\text { CDODAB } \\
\text { média } \\
(\mathrm{mM})\end{array}$ \\
\hline 100 & 0,942 & 0,989 & 0,0649 & 0,02248 & 0,4496 & \\
\hline 100 & 0,940 & 0,987 & 0,0670 & 0,02324 & 0,4647 & 0,4647 \\
\hline 100 & 0,938 & 0,985 & 0,0691 & 0,02399 & 0,4799 & \\
\hline
\end{tabular}

o Absorbância corrigida $=\operatorname{Abs} \times(\mathrm{V} \times 0.001+2) / 2$

O $\mathrm{C}_{\text {DоDAB }}$ tubo $=(\Delta \mathrm{Abs}-\mathrm{A}) / \mathrm{B}$

o $\mathrm{C}_{\text {DODAB }}$ sobrenadante $=\left(\mathrm{C}_{\text {DODAB }}\right.$ tubo $\left.\times 2000\right) / \mathrm{V}$

\section{5 - Espalhamento quasi-elástico de luz.}

A luz pode ser tratada como uma onda eletromagnética. O campo eletromagnético oscilante induz oscilações dos elétrons das partículas. Essas alterações de oscilação formam a origem da luz espalhada. Ao longo dos anos, muitas das características da luz espalhada foram usadas para determinar o tamanho de partículas. Como por exemplo:

- Mudanças na intensidade média em função do ângulo.

- Mudanças na polarização.

- Mudanças no comprimento de onda.

- Flutuações em volta da intensidade média.

Este último fenômeno é a base do espalhamento de luz quase-elástico (Quase Elastic Light Scattering - QELS) e ocorre da seguinte maneira: imagine um detector de luz fixado em um ângulo qualquer em relação à direção do feixe de luz incidente e a uma distância fixa do volume espalhador onde há um grande número de partículas dispersas. Nessa situação, luz espalhada por cada partícula alcançará o detector. Como as partículas pequenas estão se movendo no líquido aleatoriamente, realizando movimentos brownianos difusos, a distância que as ondas de luz espalhadas viajam até o detector varia em função do tempo. Sabendo que ondas eletromagnéticas exibem efeitos de interferência, as ondas espalhadas podem interferir construtiva ou destrutivamente dependo da distância que viajam ao detector, resultando em uma intensidade média com flutuações sobrepostas. 
Os tempos de decaimento das flutuações estão relacionados às constantes de difusão e, conseqüentemente, aos raios hidrodinâmicos das partículas. Partículas pequenas se movendo rapidamente, logo com coeficiente de difusão maior, causam um decaimento mais rápido das flutuações do que partículas grandes se movendo mais lentamente, logo com coeficiente de difusão menor. Os tempos de decaimento destas flutuações podem ser determinados pela análise da freqüência (que usa um analisador de espectro) ou pela análise do tempo (que usa um correlator). $\mathrm{O}$ correlator oferece geralmente o meio mais eficiente para este tipo de medida [Brookhaven, 1995]. Sua função de autocorrelação é formada pela média dos produtos das intensidades espalhadas medidas em pequenos intervalos de tempo, comparados com o tempo necessário para a flutuação voltar ou decair ao valor médio de intensidade espalhada.

\subsection{1 - Determinação da distribuição de tamanhos}

Há um grande número de técnicas utilizadas para se medir o tamanho de uma partícula, mas a técnica que utiliza o espalhamento de luz oferece muito mais vantagens: versatilidade, velocidade, medição de pequenos tamanhos e medidas de tempo independente da densidade da partícula e total preservação de amostra. A técnica envolve a espectroscopia de correlação de fóton (PCS) de espalhamento quasi-elástico de luz (QELS) e se baseia nas flutuações da intensidade da luz espalhada.

A técnica de espectroscopia de correlação de fótons (PCS) envolve determinações da autocorrelação da flutuação de intensidade média de luz espalhada, devida ao movimento browniano das partículas na dispersão, em função do tempo. Como já foi dito, partículas pequenas se movem mais rápido e causam um decaimento mais acentuado das flutuações do que as partículas grandes. O coeficiente de difusão translacional (D) está relacionado ao raio hidrodinâmico médio (R) das partículas pela equação de Stokes-Einstein. [Hanus; Ploehn, 1999]. A função de autocorrelação $g^{(1)}(2)$ é uma função do tempo. Seu decaimento está descrito por uma exponencial com constante de decaimento $\Gamma_{\mathrm{R}}$ sendo esta última proporcional ao coeficiente de difusão $D_{R}$ da partícula.

$$
g^{(1)}(2)=\sum_{R} G \exp \left(-\Gamma_{R} 2\right)
$$

A partir da função de autocorrelação pode-se obter o coeficiente de difusão, o qual está relacionado ao raio hidrodinâmico $R$ pela equação de Stokes-Einstein:

$$
\begin{gathered}
\Gamma_{R}=K^{2} D_{R} \\
D=\mathrm{K} T / 6 \pi \eta R
\end{gathered}
$$


onde $\mathrm{K}$ é a constante de Boltzmann, $\mathrm{T}$ temperatura absoluta, $\eta$ viscosidade do solvente e $\mathrm{R}$ raio hidrodinâmico médio.

Tanto as vesículas de DODAB quanto as partículas de sílica obtidas por sonicação foram dimensionadas com o uso da técnica PCS/QELS, apresentando tamanhos médios entre 70 $80 \mathrm{~nm}$ e $200-300 \mathrm{~nm}$ respectivamente. Os parâmetros do aparelho devem estar dentro do recomendado pelo fabricante para que uma boa medida seja alcançada, como a ilustrada na Figura 2.5.1.1.

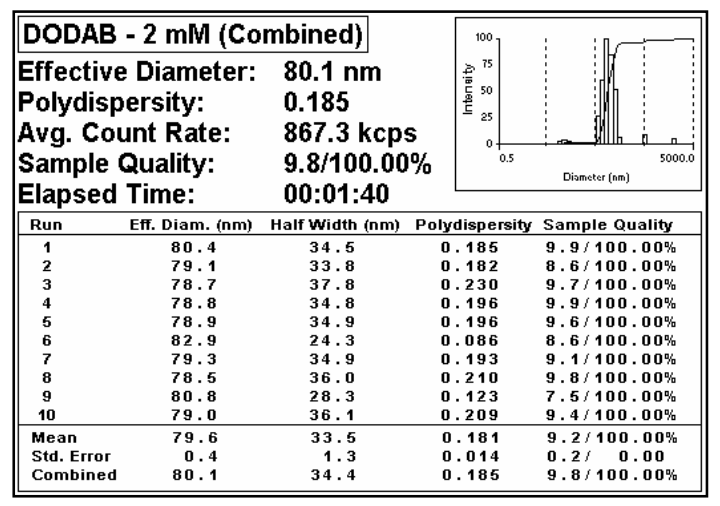

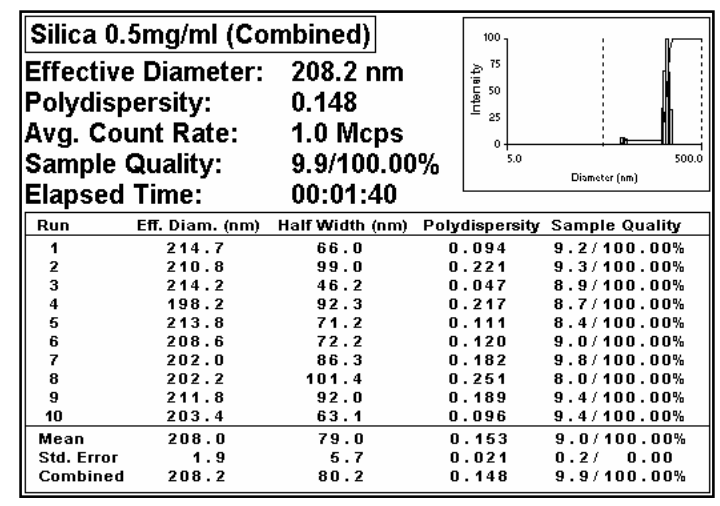

Figura 2.5.1.1 - Relatório padrão de medição da distribuição de tamanhos de vesículas de DODAB a $2 \mathrm{mM}$ e partículas de sílica a $0.5 \mathrm{mg} / \mathrm{ml}$, ambas em água, obtido no ZetaPlus.

Cada relatório exibe uma série de dez medições consecutivas realizadas pelo aparelho Zeta-Plus, onde com base nas medidas das intensidades espalhadas nos pequenos intervalos de tempo são calculados o diâmetro efetivo e meio diâmetro de partículas e polidispersidade da solução coloidal. A qualidade da amostra é estimada com base na intensidade do feixe detectado em comparação com a intensidade de um feixe de referência ('Avg. Count Rate' Figura 2.5.1.1) e seu valor deve estar entre 1 - 2 Mcps para uma qualidade de 10.0/100.00\%. O software do aparelho constrói um gráfico geral representando uma distribuição multimodal dos tamanhos de partículas como resultado, onde o eixo $\mathrm{X}$ do gráfico representa o diâmetro hidrodinâmico médio em nanômetros de uma determinada população de partículas e o eixo Y a intensidade de luz medida para a respectiva população.

\subsection{2 - Determinação do potencial-zeta}

As partículas que estão dispersas num líquido freqüentemente têm carga elétrica na sua superfície. Os possíveis mecanismos de obtenção dessas cargas são a ionização, a adsorção de íons e a dissolução iônica. Se aplicarmos um campo elétrico nestas partículas, elas se moveram para o pólo positivo ou para o pólo negativo do campo aplicado, em um processo 
conhecido como eletroforese. O sentido que elas tomam é uma indicação do sinal da carga que carregam em sua superfície. A velocidade com que elas se movem é proporcional ao valor da carga.

Assim nós necessitamos medir o sentido e a velocidade das partículas sob a influência de um campo elétrico conhecido, para que então possamos calcular a mobilidade eletroforética (movimento da superfície carregada mais íons ligados) e o potencial-zeta com esses dados. $\mathrm{Na}$ Figura 2.5.2.1 é mostrado o esquema ótico usado na determinação do potencial-zeta pelo Zeta-Plus.

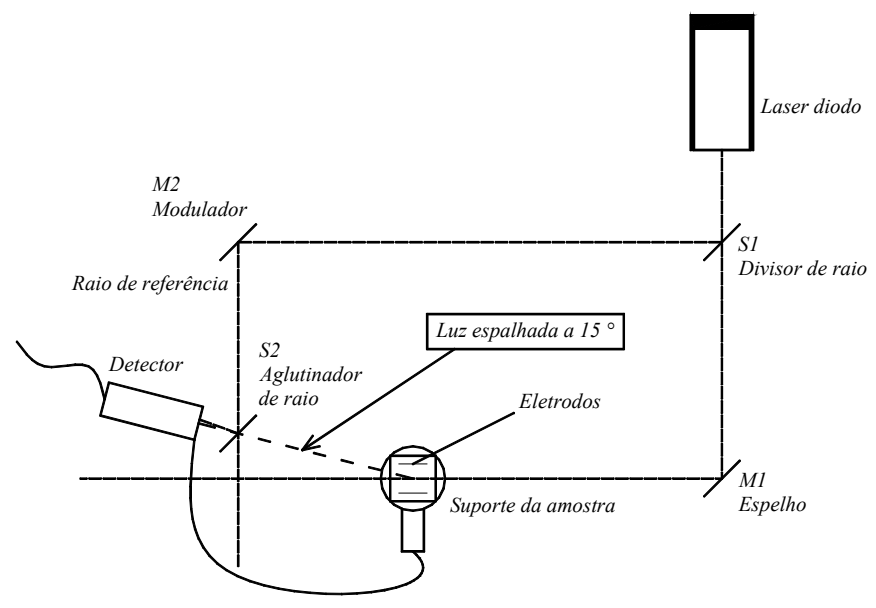

Figura 2.5.2.1 - Sistema óptico utilizado na medição do potencial zeta

Ao se aplicar um campo pulsado de baixa intensidade no líquido, teremos as partículas se movendo ora para um lado ora para o outro, sem um deslocamento espacial bruto. Ao incidir um feixe de luz laser no líquido teremos o efeito de espalhamento de luz. A freqüência de luz espalhada que chega ao detector seria ajustada por efeito Doppler e teria um valor proporcional à velocidade das partículas, que por sua vez será proporcional à sua carga. Infelizmente na prática, essas mudanças de freqüência são da ordem de $100 \mathrm{~Hz}$. Lembrandose que a freqüência do laser é da ordem de $10^{14} \mathrm{~Hz}$ - uma mudança de $10^{2}$ em $10^{14}$ é completamente impossível de detectar. Para contornar essa dificuldade, o aparelho se utiliza do fenômeno físico conhecido como heterodyning ótico, que envolve a criação de uma nova frequência de onda resultante da união de duas ondas iniciais com frequências distintas dentro de um sistema ótico não-linear. Uma parcela do feixe é desviada por um sistema ótico nãolinear (Figura 2.5.2.1), modulada a $250 \mathrm{~Hz}$ e combinada em um aglutinador com o feixe espalhado que emerge da amostra líquida. $\mathrm{O}$ feixe resultante no aglutinador teria então uma frequência proporcional aos $250 \mathrm{~Hz}$ do feixe de referência. Consequentemente, na ausência de um campo elétrico, um espectro de potência do sinal do detector teria um pico mais 
pronunciado em $250 \mathrm{~Hz}$. Agora naturalmente é fácil de detectar uma mudança de $100 \mathrm{~Hz}$ para $250 \mathrm{~Hz}$. A eletrônica-óptica está arranjada de tal modo que se o ajuste resultante for menor do que $250 \mathrm{~Hz}$, o sinal do potencial zeta é negativo e vice-versa [Brookhaven, 1997]. Esta propriedade física de todas as ondas é frequentemente utilizada na eletrônica para produzir frequências de onda baixas o suficiente para serem eficientemente processadas por aparelhos eletrônicos convencionais.

A Figura 2.5.2.2 mostra exemplos de medições feitas no ZetaPlus Zeta Potential Analyzer para as mesmas dispersões de vesículas de DODAB e partículas de sílica da Figura 2.5.1.1.

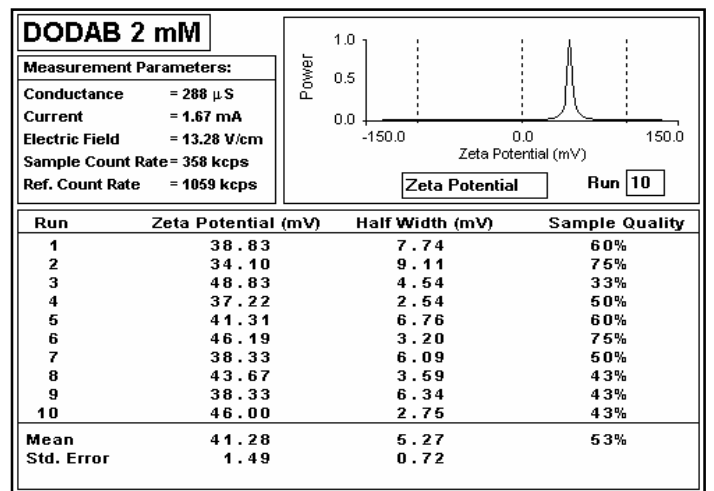

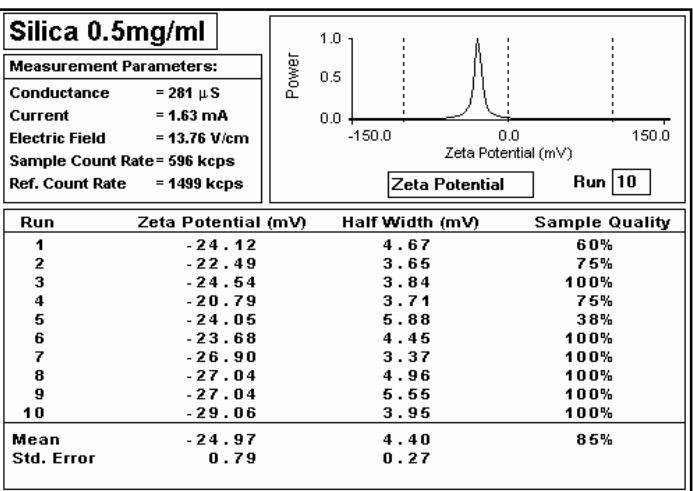

Figura 2.5.2.2 - Relatório padrão de medição do potencial-zeta de vesículas de DODAB a 2 mM e partículas de sílica a $0.5 \mathrm{mg} / \mathrm{ml}$, ambas em água, obtido no ZetaPlus.

Para cada amostra são realizadas 10 medições consecutivas, feitas automaticamente pelo Zeta-Plus, do efeito Doppler produzido pelas partículas sob a influência do campo elétrico. O efeito Doppler é indicativo da velocidade que é indicativa da carga de superfície, permitindo assim o cálculo do potencial-zeta da amostra, como definido pela Figura 1.3.1.3. É importante a manutenção de uma condutância ótima do meio aquoso de $\pm 300 \mu \mathrm{S}$ assim como uma contagem de referência de $\pm 1000 \mathrm{kcps}$, para a obtenção de uma qualidade de leitura de $100 \%$. O resultado é ilustrado em um gráfico de pico de intensidade verso potencial-zeta $(\mathrm{mV})$.

\section{6 - Interação entre as vesículas de DODAB e as partículas de sílica}

A interação entre vesículas de DODAB e partículas de sílica foi induzida pela adição de vesículas às partículas em tubos de ensaio ou eppendorfs fechados, seguida de agitação por alguns minutos. Essas interações ocorreram à temperatura ambiente $\left(25^{\circ} \mathrm{C}\right)$ ou a temperaturas acima de $42^{\circ} \mathrm{C}$ que é o ponto de transição de fase para bicamadas de DODAB, dependendo do experimento. 


\subsection{1 - Determinação do tamanho e do potencial-zeta das partículas}

As condições experimentais para este experimento foram:

- variação na concentração de DODAB: $0,0.05,0.1,0.2,0.3,0.5,1.0 \mathrm{mM}$.

- variação na concentração de $\mathrm{KCl}: 0,0.1,0.5,1.0,10.0 \mathrm{mM}$.

- todos os tubos de interação continham $0.1 \mathrm{mg} / \mathrm{ml}$ de sílica em $3 \mathrm{ml}$ de mistura o que representa uma área superficial total de $0.078 \mathrm{~m}^{2}$ de sílica por tubo (assumindo a área superficial específica da sílica como $26 \mathrm{~m}^{2} / \mathrm{g}$ ).

- após 24 horas de interação em repouso, alíquotas de $2 \mathrm{ml}$ do sobrenadante foram retiradas de cada tubo de interação e submetidas à medição do tamanho das partículas e potencial-zeta no ZetaPlus.

\subsection{2 - Determinação da agregação das partículas por turbidez ou por sedimentação.}

As condições experimentais para este experimento foram:

- variação na concentração de DODAB: 0, 0.05, 0.1, 0.2, 0.3, 0.5, 0.6, 1.0 mM.

- variação na concentração de $\mathrm{KCl}: 0,0.1,0.5,1.0,10.0 \mathrm{mM}$.

- todos os tubos de interação continham $2 \mathrm{mg} / \mathrm{ml}$ de sílica em $10 \mathrm{ml}$ de mistura o que representa uma área superficial total de $0.52 \mathrm{~m}^{2}$ de sílica por tubo (assumindo a área superficial específica da sílica como $26 \mathrm{~m}^{2} / \mathrm{g}$ ).

- foram tiradas 5 séries de 8 fotos digitais em 2 intervalos de tempo isolados, ou seja, para cada uma das cinco concentrações de $\mathrm{KCl}$ foi feito um arranjo de oito tubos de interação variando de um para outro somente a concentração de DODAB, tirando fotos 30 minutos e 4 horas após a interação.

- a turbidez de cada mistura foi medida no espectrofotômetro como medida de absorbância (Abs) nos dois intervalos de tempo e para as concentrações de DODAB de 0, 0.05 e $1.0 \mathrm{mM}$ em cada uma das cinco concentrações de $\mathrm{KCl}$. Para isso, dado o intervalo de tempo determinado, uma alíquota de cada mistura $(2 \mathrm{ml})$ foi retirada e medida no aparelho em uma cubeta de plástico em contraste com uma solução de referência padrão de água pura na faixa de comprimento de onda de $480 \mathrm{~nm}$.

- após a medida da turbidez, a mesma alíquota foi então submetida a uma medida da sua mobilidade eletroforética no ZetaPlus. Feito isso, a alíquota é então retornada ao tubo de interação para a continuidade do experimento (se necessário). 
A medição da turbidez foi aqui empregada para melhor ilustrar a floculação de sílica nos tubos e foi também empregada em outros experimentos isolados, sempre com a mesma concentração de $2 \mathrm{mg} / \mathrm{ml}$ de sílica, para se obter uma visão geral deste processo de floculação.

A medição do potencial zeta (pela mobilidade eletroforética) foi empregada para detectar quaisquer variações na carga de superfície das partículas de sílica recobertas.

Quando necessário dispersões de sílica foram submetidas a aquecimento antes ou depois da interação com as vesículas até temperaturas acima da de transição de fase destas, ou submetidas a nova sonicação depois da interação com as vesículas.

Um método alternativo envolveu um dinamômetro utilizado como uma balança de sedimentação para acompanhar a cinética de sedimentação das partículas de sílica induzida por interação com o DODAB. Neste procedimento o aparelho foi ajustado no modo de balança de sedimentação onde uma pequena balança de metal (Figura 2.6.2.1) é conectada ao transdutor do aparelho. Após a interação das partículas de sílica com as vesículas de DODAB em um béquer apropriado, a mistura foi colocada na base móvel do aparelho. A base então é erguida em direção à balança suspensa até que esta esteja completamente mergulhada na mistura e preferencialmente afundada até a base do béquer. Feito isso o aparelho é acionado, zerado e a balança procede com a medição da massa em gramas de material sedimentado em função do tempo. A calibração do aparelho no modo de balança é feita com um par de pequenos pesos de 1.0 e 0.5 grama.

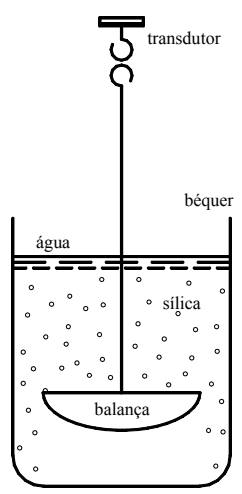

Figura 2.6.2.1 - Determinação da cinética de sedimentação de sílica em presença de DODAB com o uso da balança de sedimentação de um dinamômetro.

O resultado obtido é uma curva de massa sedimentada em função do tempo, sendo o tempo zero o instante inicial em que é feita a interação sílica-vesícula. A desvantagem deste método se refere à detecção de cinéticas muito rápidas de sedimentação por exemplo quando as partículas de sílica sedimentam quase que instantaneamente por interação com as vesículas 
de $\mathrm{DODAB}$, o que cria uma certa dificuldade no procedimento experimental quanto a estabelecer um tempo zero confiável (de sedimentação zero).

\section{7 - Determinação da adsorção de bicamadas sobre as partículas de sílica}

A interação entre vesículas e partículas foi induzida pela adição de vesículas às partículas e vortexação por alguns minutos em eppendorf fechado. As misturas de sílica e vesículas forma termostatizadas a uma temperatura acima da temperatura de transição de fase das bicamadas por uma hora. No caso do DODAB a temperatura utilizada foi de $42^{\circ} \mathrm{C}$.

Todas as misturas de $2 \mathrm{ml}$ continham $1 \mathrm{mg} / \mathrm{ml}$ de sílica, o que representa uma área superficial total de $0.052 \mathrm{~m}^{2}$ (assumindo a área superficial específica $26 \mathrm{~m}^{2} / \mathrm{g}$ - BET e titulação potenciométrica). Após o tempo de interação de 1 hora, as misturas foram centrifugadas a $14,000 \mathrm{rpm}$ por uma hora a $15^{\circ} \mathrm{C}$ para separar partículas de vesículas. $\mathrm{O}$ sobrenadante foi utilizado para determinar a concentração de DODAB, e junto com a área superficial específica e massa da dispersão de sílica em cada mistura foram obtidas as isotermas de adsorção para o anfifílico sobre as partículas. A Tabela 2.7.1 mostra o protocolo utilizado para determinação das isotermas de adsorção e Tabela 2.7.2 mostra a planilha de cálculo utilizada para calcular a quantidade de moléculas de DODAB adsorvida por metro quadrado de sílica.

Tabela 2.7.1 - Protocolo para determinação das isotermas de adsorção entre vesículas de DODAB e partículas de sílica em presença de força iônica de $\mathrm{KCl}$.

\begin{tabular}{|c|c|c|c|c|c|}
\hline \multicolumn{4}{|c|}{$\begin{array}{l}\text { Volume da amostra: } \\
\text { Concentração de sílica no tubo: } \\
\text { Concentração de sal no tubo: }\end{array}$} & \multicolumn{2}{|c|}{$\begin{array}{l}1 \mathrm{mg} / \mathrm{ml} \\
0.5 \mathrm{mM}\end{array}$} \\
\hline \multirow[t]{2}{*}{$\begin{array}{l}\mathrm{N}^{\circ} \mathrm{da} \\
\text { mistura }\end{array}$} & \multicolumn{2}{|c|}{$\begin{array}{l}\text { Volume de } \\
\text { vesícula } \\
2.000 \\
\mathrm{mM} \\
\end{array}$} & \multirow[t]{2}{*}{$\begin{array}{c}\text { Volume de } \\
\text { sílica } \\
4 \\
\mathrm{mg} / \mathrm{ml} \\
(\mu \mathrm{l})\end{array}$} & \multirow[t]{2}{*}{$\begin{array}{c}\text { Volume de slç } \\
\text { de } \mathrm{KCl} \\
10 \\
\mathrm{mM} \\
(\mu 1) \\
\end{array}$} & \multirow[t]{2}{*}{$\begin{array}{c}\text { Volume para } \\
\text { completar } \\
\mathrm{H}_{2} \mathrm{O} \\
(\mu \mathrm{l})\end{array}$} \\
\hline & $(\mathrm{mM})$ & $(\mu 1)$ & & & \\
\hline 1 & 0.040 & 40 & 500 & 100 & 1360 \\
\hline 2 & 0.050 & 50 & 500 & 100 & 1350 \\
\hline 3 & 0.100 & 100 & 500 & 100 & 1300 \\
\hline 4 & 0.200 & 200 & 500 & 100 & 1200 \\
\hline 5 & 0.300 & 300 & 500 & 100 & 1100 \\
\hline 6 & 0.400 & 400 & 500 & 100 & 1000 \\
\hline 7 & 0.500 & 500 & 500 & 100 & 900 \\
\hline 8 & 0.600 & 600 & 500 & 100 & 800 \\
\hline 9 & 0.700 & 700 & 500 & 100 & 700 \\
\hline 10 & 0.800 & 800 & 500 & 100 & 600 \\
\hline 11 & 0.900 & 900 & 500 & 100 & 500 \\
\hline 12 & 1.000 & 1000 & 500 & 100 & 400 \\
\hline
\end{tabular}


Tabela 2.7.2 - Planilha para calcular a quantidade de moléculas de DODAB adsorvidas por metro quadrado de sílica.

\begin{tabular}{|c|c|c|c|c|c|c|c|c|c|c|c|}
\hline $\mathrm{N}^{\circ}$ & $\begin{array}{c}\text { CDODAB } \\
\text { adicion. } \\
(\mathrm{mM})\end{array}$ & $\begin{array}{l}\text { VDODAB } \\
\qquad(\mu 1)\end{array}$ & $\begin{array}{c}\text { Abs } \\
(480 \mathrm{~nm})\end{array}$ & $\begin{array}{l}\text { Abs } \\
\text { (corr.) }\end{array}$ & $\begin{array}{c}\Delta \mathrm{Abs} \\
\text { (br-cor) }\end{array}$ & $\begin{array}{c}\text { CDODAB } \\
\text { tubo } \\
(\mathrm{mM})\end{array}$ & $\begin{array}{c}\text { CDODAB } \\
\text { sobr. } \\
(\mathrm{mM})\end{array}$ & $\begin{array}{c}\text { CDODAB } \\
\text { média } \\
(\mathrm{mM})\end{array}$ & $\begin{array}{c}\text { CDODAB } \\
\text { adsorv. } \\
(\mathrm{mM})\end{array}$ & $\begin{array}{c}\mathrm{N}^{\circ} \text { de } \\
\text { moléculas }\end{array}$ & $\begin{array}{c}\mathrm{N}^{\circ} \mathrm{de} \\
\text { moléculas/área }\end{array}$ \\
\hline $\begin{array}{l}1 \\
1 \\
1\end{array}$ & 0,05 & $\begin{array}{l}100 \\
100 \\
100 \\
\end{array}$ & $\begin{array}{l}1,003 \\
1,003 \\
1,007 \\
\end{array}$ & $\begin{array}{l}1,053 \\
1,053 \\
1,057\end{array}$ & $\begin{array}{l}-0,0004 \\
-0,0004 \\
-0,0046\end{array}$ & $\begin{array}{r}-0,003 \\
-0,003 \\
-0,004\end{array}$ & $\begin{array}{l}-0,0599 \\
-0,0599 \\
-0,0918\end{array}$ & 0,0000 & 0,0500 & $6,02 \mathrm{E}+16$ & $1,1577 \mathrm{E}+18$ \\
\hline $\begin{array}{l}2 \\
2 \\
2\end{array}$ & 0,10 & $\begin{array}{l}100 \\
100 \\
100\end{array}$ & $\begin{array}{l}0,999 \\
0,999 \\
0,999\end{array}$ & $\begin{array}{l}1,049 \\
1,049 \\
1,049\end{array}$ & $\begin{array}{l}0,0038 \\
0,0038 \\
0,0038\end{array}$ & $\begin{array}{l}-0,001 \\
-0,001 \\
-0,001\end{array}$ & $\begin{array}{l}-0,0280 \\
-0,0280 \\
-0,0280\end{array}$ & 0,0000 & 0,1000 & $1,20 \mathrm{E}+17$ & $2,3154 \mathrm{E}+18$ \\
\hline $\begin{array}{l}3 \\
3 \\
3\end{array}$ & 0,20 & $\begin{array}{l}100 \\
100 \\
100\end{array}$ & $\begin{array}{l}0,989 \\
0,992 \\
0,986\end{array}$ & $\begin{array}{l}1,038 \\
1,042 \\
1,035\end{array}$ & $\begin{array}{l}0,0143 \\
0,0112 \\
0,0175\end{array}$ & $\begin{array}{l}0,002 \\
0,001 \\
0,004\end{array}$ & $\begin{array}{l}0,0518 \\
0,0279 \\
0,0757\end{array}$ & 0,0518 & 0,1482 & $1,78 \mathrm{E}+17$ & $3,4314 \mathrm{E}+18$ \\
\hline $\begin{array}{l}4 \\
4 \\
4\end{array}$ & 0,40 & $\begin{array}{l}100 \\
100 \\
100\end{array}$ & $\begin{array}{l}0,959 \\
0,957 \\
0,959\end{array}$ & $\begin{array}{l}1,007 \\
1,005 \\
1,007\end{array}$ & $\begin{array}{l}0,0458 \\
0,0479 \\
0,0458\end{array}$ & $\begin{array}{l}0,014 \\
0,015 \\
0,014 \\
\end{array}$ & $\begin{array}{l}0,2911 \\
0,3070 \\
0,2911\end{array}$ & 0,2964 & 0,1036 & $1,25 \mathrm{E}+17$ & $2,3987 \mathrm{E}+18$ \\
\hline $\begin{array}{l}5 \\
5 \\
5\end{array}$ & 0,60 & $\begin{array}{l}100 \\
100 \\
100\end{array}$ & $\begin{array}{l}0,930 \\
0,930 \\
0,930\end{array}$ & $\begin{array}{l}0,977 \\
0,977 \\
0,977\end{array}$ & $\begin{array}{l}0,0763 \\
0,0763 \\
0,0763\end{array}$ & $\begin{array}{l}0,025 \\
0,025 \\
0,025\end{array}$ & $\begin{array}{l}0,5224 \\
0,5224 \\
0,5224\end{array}$ & 0,5224 & 0,0776 & $9,34 \mathrm{E}+16$ & $1,7967 \mathrm{E}+18$ \\
\hline $\begin{array}{l}6 \\
6 \\
6\end{array}$ & 0,80 & $\begin{array}{l}100 \\
100 \\
100\end{array}$ & $\begin{array}{l}0,902 \\
0,902 \\
0,901\end{array}$ & $\begin{array}{l}0,947 \\
0,947 \\
0,946\end{array}$ & $\begin{array}{l}0,1057 \\
0,1057 \\
0,1068\end{array}$ & $\begin{array}{l}0,036 \\
0,036 \\
0,036\end{array}$ & $\begin{array}{l}0,7457 \\
0,7457 \\
0,7537\end{array}$ & 0,7484 & 0,0516 & $6,22 \mathrm{E}+16$ & $1,1955 \mathrm{E}+18$ \\
\hline $\begin{array}{l}7 \\
7 \\
7\end{array}$ & 1,00 & $\begin{array}{l}100 \\
100 \\
100\end{array}$ & $\begin{array}{l}0,869 \\
0,876 \\
0,866\end{array}$ & $\begin{array}{l}0,912 \\
0,920 \\
0,909\end{array}$ & $\begin{array}{l}0,1404 \\
0,1330 \\
0,1435\end{array}$ & $\begin{array}{l}0,048 \\
0,045 \\
0,049\end{array}$ & $\begin{array}{l}1,0089 \\
0,9531 \\
1,0329\end{array}$ & 0,9983 & 0,0017 & $2,05 \mathrm{E}+15$ & $3,9362 \mathrm{E}+16$ \\
\hline
\end{tabular}




\section{3 - Resultados e discussão}

Teoricamente, as unidades ou fragmentos de bicamadas recobrem a sílica de maneira a se depositarem paralelamente à sua superfície como indicado na Figura 3.1. Isso ocorre devido à presença de forte atração eletrostática que existe entre a superfície dos fragmentos de DODAB e a superfície de sílica.

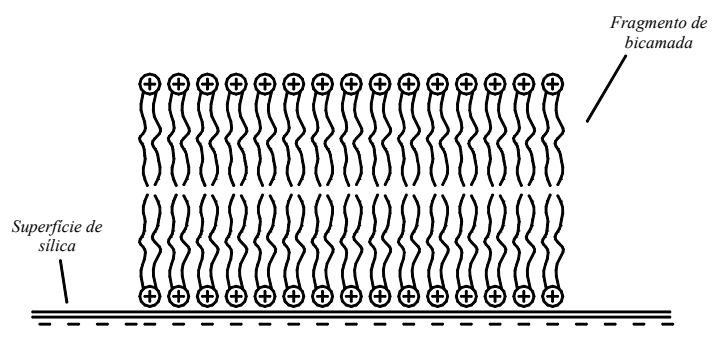

Figura 3.1 - Representação esquemática da maneira como um fragmento de bicamada se deposita sobre a superfície de sílica. A ação da força eletrostática é representada pelas cargas + e - de cada espécie.

Quando a área superficial de bicamadas adicionada for igual à área superficial das partículas de sílica presentes em solução (relação $\frac{A_{D D D A B}}{A_{\text {silica }}}=1$ ), significa que toda a superfície de sílica pode ser recoberta perfeitamente pelas bicamadas de DODAB o que resulta em uma estabilização coloidal devido à força eletrostática semelhante à que ocorre no caso da sílica coloidal em água pura. Este efeito está esquematizado na Figura 3.2.

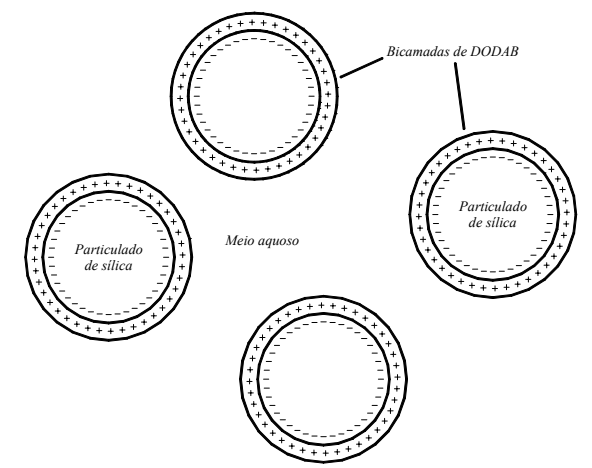

Figura 3.2 - Representação do processo de estabilização de partículas pequenas de sílica perfeitamente recobertas por bicamadas de DODAB. A área superficial de bicamadas deve ser igual à área superficial de sílica.

Com base nas concentrações de sílica e de DODAB em solução, pode-se calcular a relação de área superficial que existe entre estes componentes. A Equação 3.1.1 calcula a área de bicamadas de DODAB em solução em um dado volume:

$$
A_{b}=\frac{C \cdot V \cdot 6.02 \cdot 10^{23} \cdot 0.6}{2 \cdot 10^{18}}
$$

onde $C$ é a concentração de DODAB em molar e $V$ o volume da amostra em litros. Sendo 6.02 x $10^{23}$ o número de Avogadro, 0.6 o valor da área da base de um cilindro equivalente a uma molécula de DODAB em $\mathrm{nm}^{2}$ (área da cabeça polar do DODAB a $25^{\circ} \mathrm{C}$ ), 2 o parâmetro 
referente a uma bicamada e $10^{18}$ a conversão de $\mathrm{nm}^{2}$ para $\mathrm{m}^{2}$. Associando esta equação com o cálculo da área superficial de sílica em solução em um dado volume, obtém-se a fórmula para a relação $\mathbf{R}$ entre as áreas:

$$
R=\frac{A_{b}}{A_{s}}=\frac{C_{D O D A B} \cdot 6.02 \cdot 10^{23} \cdot 0.6}{C_{\text {silica }} \cdot 2 \cdot 26 \cdot 10^{18}}
$$

onde $C_{D O D A B}$ é a concentração de DODAB em molar e $C_{\text {silica }}$ a concentração de sílica em $\mathrm{mg} / \mathrm{ml}$. Sendo 26 o valor da área superficial específica da sílica $\mathrm{em} \mathrm{m}^{2} / \mathrm{g}$ calculada por BET.

\section{1 - Adsorção de DODAB em sílica}

\subsection{1 - Efeito da força iônica}

A Figura 3.1.1.1 mostra a adsorção de moléculas de DODAB a partir de fragmentos de bicamadas de DODAB sobre a superfície da sílica a $\mathrm{pH}$ da água (6.3) em quatro diferentes forças iônicas $(0,0.1,0.5$ e $1.0 \mathrm{mM}$ de $\mathrm{KCl}$ ou Tris- $\mathrm{HCl})$.

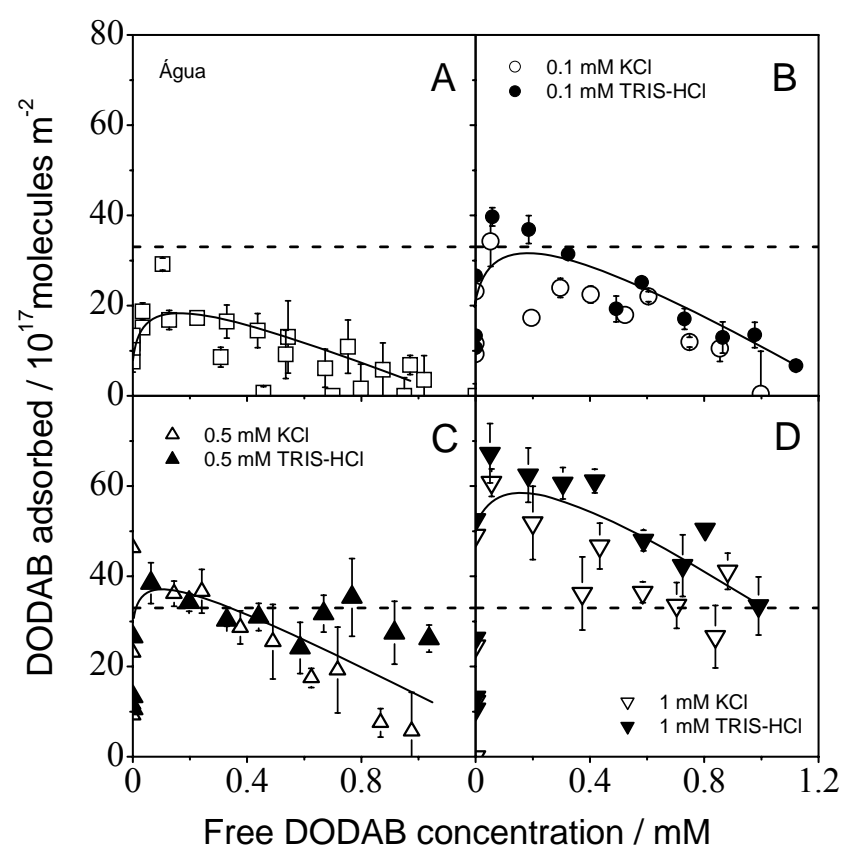

Figura 3.1.1.1 - Adsorção de DODAB por metro quadrado de sílica (1 mg/ml) em soluções com 0 (A), 0.1 (B), 0.5 (C) e $1.0 \mathrm{mM}$ (D) de $\mathrm{KCl}$ ou Tris- $\mathrm{HCl}$ a pH $6.3,25^{\circ} \mathrm{C}$. A linha pontilhada representa a adsorção esperada para a deposição de uma única bicamada de DODAB em cada partícula de sílica, tomando $0.6 \mathrm{~nm}^{2}$ como a área da cabeça polar de cada molécula de DODAB adsorvida na superfície.

O aumento inicial da adsorção é característico da alta afinidade entre espécies adsorventes e o adsorbato. Com a elevação da força iônica (Figura 3.1.1.1 A - D) a afinidade do DODAB pela sílica e o máximo de adsorção aumentaram. $\mathrm{O}$ aumento da dissociação dos grupos silanóis com a força iônica e pH sempre conduz a um aumento de densidade de carga de particulados de sílica (Tadros \& Lyklema, 1968) conforme discutido no Capítulo 1.3.1. 
Portanto, a atração eletrostática do DODAB pela superfície da partícula também aumentaria. Entretanto, em contraste com a concentração do sal, a natureza dele não afetou a adsorção do DODAB na sílica como pode ser visto pelas isotermas muito parecidas de $\mathrm{KCl}$ e TRIS-HCl. Portanto, a adsorção específica dos contra íons catiônicos do TRIS-HCl (Figura 3.1.1.2) na superfície da sílica pareceu estar ausente ao menos nas faixas de concentração estudadas de $0.1-1.0 \mathrm{mM}$.

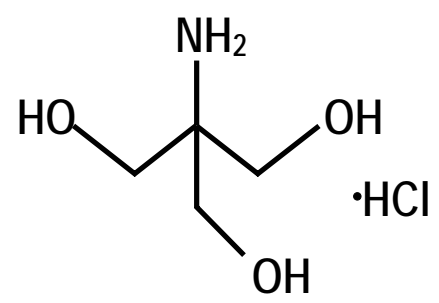

Figura 3.1.1.2 - Fórmula do TRIS-HCl $(\mathrm{pKa}=8.08)$

A forma das isotermas de adsorção de DODAB na Figura 3.1.1.1 indica uma adsorção com alta afinidade e um pico máximo que representa um comportamento típico de competição entre a superfície da sílica e outro adsorvente na mistura. Como as misturas continham somente sílica e fragmentos de bicamadas de DODAB, o outro adsorvente somente poderia ser os fragmentos de bicamadas livres em solução não adsorvidos na superfície da sílica, que atrairiam hidrofobicamente os fragmentos adsorvidos. De fato, a adsorção competitiva na sílica observada neste trabalho ao longo de uma faixa de forças iônicas também fora previamente observada em uma faixa de pHs [Rapuano \& Carmona-Ribeiro, 1997, Rapuano \& Carmona-Ribeiro, 2000] e em interações de fragmentos de bicamadas de DODAB com partículas poliméricas em água pura ou a $1 \mathrm{mM}$ de força iônica [Tsuruta \& Carmona-Ribeiro, 1996].

\subsection{2 - Efeito da densidade de carga da silica.}

A Figura 3.1.2.1 mostra a adsorção de DODAB em sílica determinada por Rapuano e Carmona-Ribeiro [Rapuano \& Carmona-Ribeiro, 1997, Rapuano \& Carmona-Ribeiro, 2000] em diferentes valores de $\mathrm{pH}$ e força iônica fixa em $10 \mathrm{mM}$, e determinações de adsorção de DODAB deste trabalho a pH 6.3 e $1.0 \mathrm{mM}$ de força iônica (Figura 3.1.1.1 D).

Em cada condição experimental, as densidades de carga superficial das partículas de sílica foram determinadas por titulação potenciométrica por Tadros e Lyklema [Tadros \& Lyklema, 1968] e adsorção de DODAB nestas condições foi plotada em função dessas densidades de 
carga (Figura 3.1.2.1). Houve uma correlação direta entre a adsorção de DODAB e a densidade de carga de partícula, com a adsorção se aproximando de zero para densidades de cargas muito pequenas. Isso sugere um papel importante da atração eletrostática na adsorção do DODAB sobre o particulado.

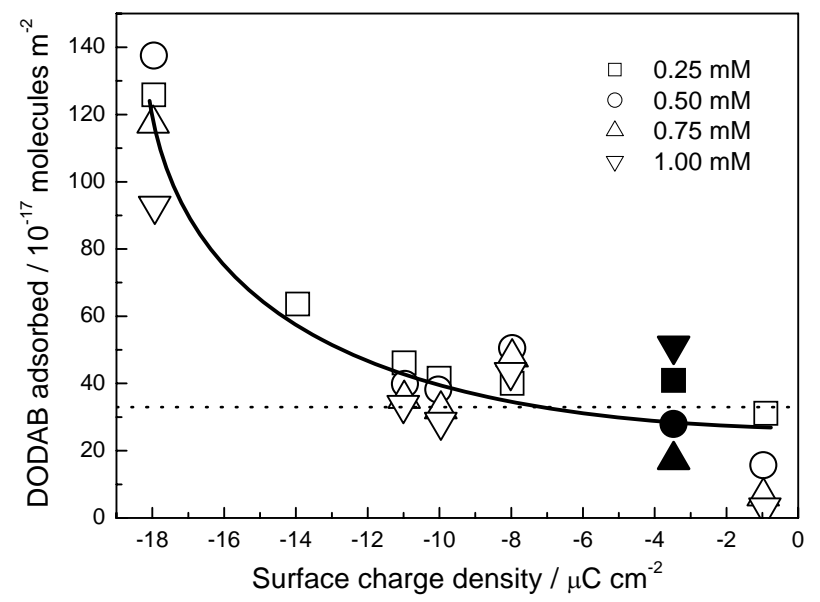

Figura 3.1.2.1 - Decréscimo exponencial da adsorção de DODAB em função da densidade de carga superficial das partículas de sílica em quatro diferentes concentrações de DODAB restante no sobrenadante (símbolos diferentes). Os símbolos vazios representam dados obtidos anteriormente e os símbolos cheios representam dados atuais da Figura 3.1.1.1 D (como descrito no texto). A linha pontilhada representa a adsorção esperada para a deposição de uma única bicamada de DODAB em cada partícula de sílica.

A adsorção equivalente a uma única bicamada recobrindo a sílica deve estar por volta de $33-40 \times 10^{17}$ moléculas de DODAB por metro quadrado de sílica. Esses valores somente foram atingidos quando os fragmentos de bicamadas adsorvidos em excesso (representados pelos picos de adsorção na Figura 3.1.1.1 C e D) foram removidos da superfície pelos fragmentos livres em solução. Em água pura ou forças iônicas extremamente baixas $(\leq 0.1$ $\mathrm{mM}$ de sal), entretanto, as densidades de carga na sílica são muito baixas (Figura 3.1.2.1) para assegurar uma quantidade de adsorção consistente com um recobrimento perfeito de bicamada. Nestes casos, provavelmente, "discos" dispersos de bicamadas estavam adsorvidos na superfície da sílica (Figura 3.1.1.1 A e B). Resumindo, uma adsorção consistente com um recobrimento de uma única bicamada, $33-40 \times 10^{17}$ moléculas de DODAB por $\mathrm{m}^{2}$ de sílica, deve ocorrer na faixa de densidade de carga de partícula entre -6 e $-9 \mu \mathrm{C} / \mathrm{cm}^{2}$ em $10 \mathrm{mM}$ de força iônica.

Lembrando-se da natureza hidrofóbica das bordas rodeando os fragmentos de bicamadas, com os atuais resultados relativos à competição entre componentes eletrostáticos, fragmentos de bicamadas positivamente carregadas e partículas de sílica negativamente carregadas, e as interações hidrofóbicas, que levaram fragmentos livres de bicamadas a "seqüestrar" fragmentos já adsorvidos na superfície da sílica, um possível efeito da elevação da polaridade 
do meio com o aumento da força iônica deve ser considerado. Possivelmente, aumentando-se a polaridade do meio (Figura 3.1.1.1 A - D), fragmentos adjacentes de bicamadas na sílica acabariam se fundindo até que os discos isolados de bicamadas na superfície da sílica formassem eventualmente uma única e contínua estrutura de bicamada. A situação ideal de uma bicamada contínua e perfeitamente selada em partículas pode eventualmente evitar o "seqüestro" de fragmentos adsorvidos por fragmentos livres. Sais monovalentes em concentrações um pouco mais elevadas que as utilizadas neste trabalho $(10-50 \mathrm{mM} \mathrm{NaCl})$ foram de fato relatados como fusogênicos ao serem adicionados a fragmentos de bicamadas de DODAB [Carmona-Ribeiro et al. 1984, Carmona-Ribeiro, 1986, Carmona-Ribeiro, 1993a \& 1993b]. Assim, ainda resta a possibilidade de que fragmentos adjacentes e muito próximos depositados sobre as partículas possam eventualmente se fundir em uma faixa de forças iônicas baixas e controladas como aquelas usadas neste trabalho.

\section{2 - Estabilidade coloidal em função da razão de área $R$}

Com o aumento da concentração de DODAB adicionado a dispersões diluídas de sílica de concentrações fixas, o valor de $A_{b}$ (Eq. 3.1.1) aumenta e portanto o efeito de $\mathrm{R}$ sobre o potencial-zeta $(\zeta)$ e o diâmetro médio de partícula $\left(D_{Z}\right)$ pôde ser analisado.

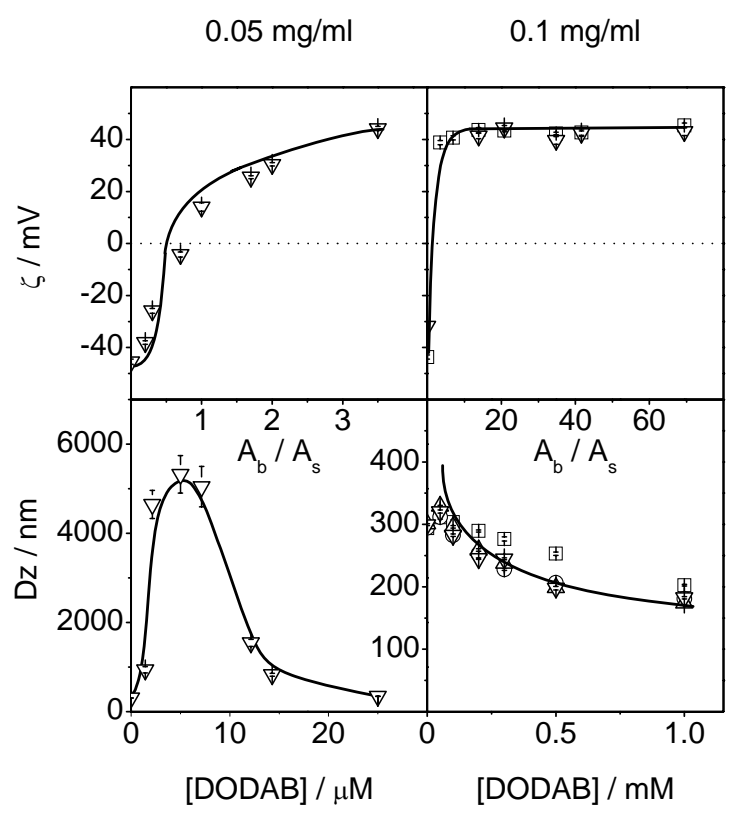

Figura 3.2.1 - Efeito da concentração de DODAB no potencial-zeta $(\zeta)$ e diâmetros médios $\left(\mathrm{D}_{\mathrm{Z}}\right)$ da sílica $(0.05$ ou $0.1 \mathrm{mg} / \mathrm{ml})$ em $0(\square), 0.1(\bigcirc), 0.5(\triangle)$, e $1.0 \mathrm{mM}$ de $\mathrm{KCl}(\nabla)$. Paralelamente, a concentração de DODAB foi expressa em função de $\mathrm{R}=\mathrm{A}_{\mathrm{b}} / \mathrm{A}_{\mathrm{s}}$.

Na Figura 3.2.1 A, com o aumento de $\mathrm{R}$, uma dependência sigmoidal $\zeta$ em $\mathrm{R}$ foi obtida. Um potencial-zeta de aproximadamente $40 \mathrm{mV}$ foi atingido para partículas recobertas nos 
valores mais elevados de $\mathrm{R}$. A curva sigmoidal mudou sua concavidade no ponto de $\mathrm{R}=0.5 \mathrm{e}$ $\zeta=0$. Este ponto define a situação onde a mobilidade eletroforética média das partículas na dispersão é igual a zero o que resultaria em uma estabilização eletrostática ausente e uma baixa estabilidade coloidal. De fato, isso foi observado na Figura 3.2.1 C onde um máximo em $\mathrm{D}_{\mathrm{Z}}$, ou um mínimo de estabilidade coloidal, foi atingido em $\mathrm{R}=0.5$ e $\zeta=0$, ao passo que a minimização de tamanho, ou elevação da estabilidade coloidal, somente ocorreu em valores de $\mathrm{R} \geq 1$, a região onde os maiores valores positivos de $\zeta$ foram medidos.

As Figuras 3.2.1 B e D enfatizam a minimização de tamanho ao longo de uma faixa mais elevada e ampla de concentrações de $\operatorname{DODAB}(\mathrm{R}>>3)$ em quatro diferentes forças iônicas, pH $6.5(0,0.1,0.5,1.0 \mathrm{mM} \mathrm{KCl})$. Em um potencial-zeta de aproximadamente $40 \mathrm{mV}$, para $\mathrm{R}$ >> 3, a minimização do tamanho de partículas foi observada para todas as forças iônicas empregadas no experimento (Figura 3.2.1 B e D).

A estabilidade coloidal das partículas de sílica a $2 \mathrm{mg} / \mathrm{ml}$ de sílica em $1 \mathrm{mM}$ de $\mathrm{KCl}$ foi acompanhada por cinéticas de sedimentação. Nessas elevadas densidades de partículas, em água pura, a sílica sozinha já produz alguns sedimentos em função do tempo como pode ser visto na Figura 3.2.2.

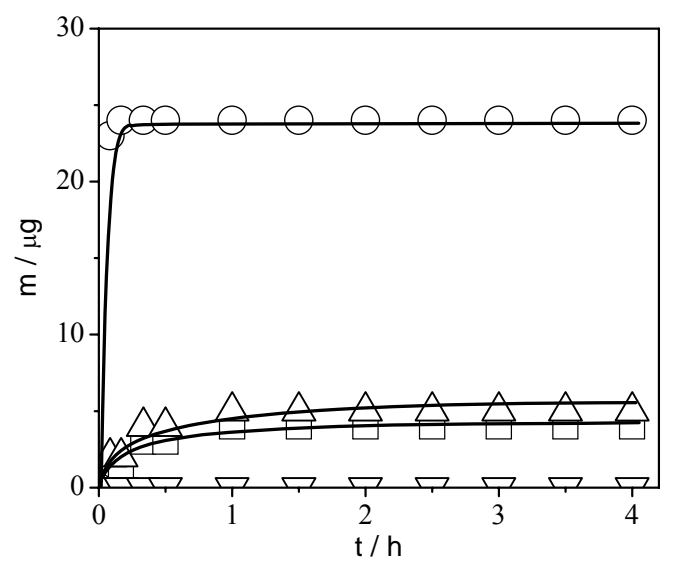

Figura 3.2.2 - Massa sedimentada de sílica em função do tempo após a adição de fragmentos de bicamadas de DODAB à dispersão de sílica para concentrações finais iguais a $0(\square), 0.01(\bigcirc), 0.3(\triangle)$ e $0.6 \mathrm{mM}$ de DODAB $(\nabla)$.

Quando a razão de áreas R é menor do que 1, ocorre uma rápida e extensa sedimentação típica da formação de grandes agregados. Em contrapartida, foi obtida uma estabilização em valores de $\mathrm{R}$ maiores que 1 , evidenciada por velocidades de sedimentação próximas a zero, ou seja, partículas de sílica perfeitamente estáveis e dispersas obtidas através do recobrimento completo por fragmentos de bicamadas de DODAB. Deve-se notar que a estabilidade coloidal de partículas de sílica recobertas por bicamadas foi aumentada em relação à da sílica sozinha. 
Uma análise sistemática da estabilidade coloidal, em função da força iônica (0 - $10 \mathrm{mM}$ de $\mathrm{KCl}$ ) e da concentração de DODAB ou da razão de áreas R, é mostrada na Figura 3.2.3.

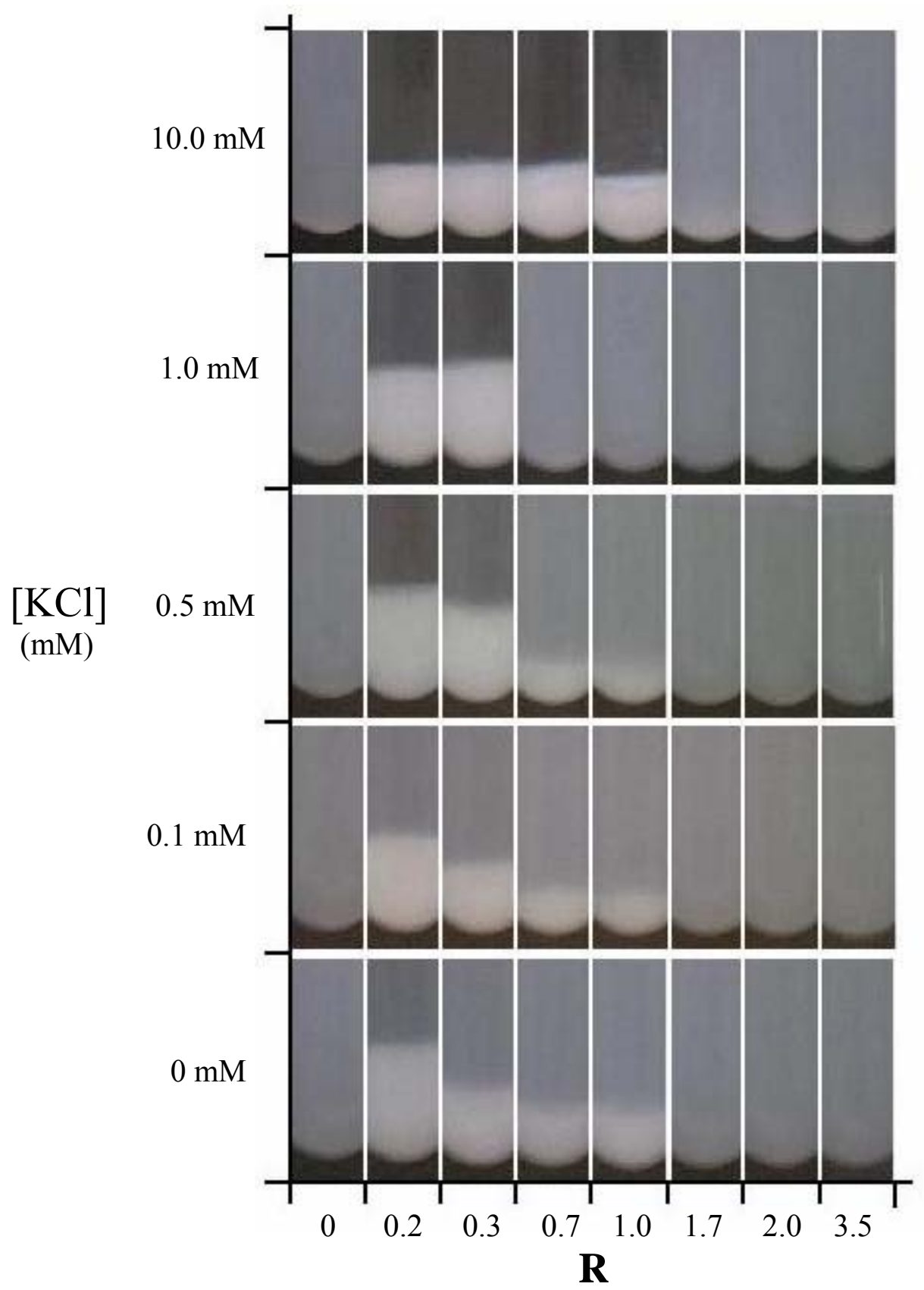

Figura 3.2.3 - Fotografias de tubos de ensaio contendo $2 \mathrm{mg} / \mathrm{ml}$ de sílica incubada com fragmentos de bicamada de $\operatorname{DODAB}\left(2 \mathrm{~h}, 25^{\circ} \mathrm{C}, \mathrm{pH} 6.5\right)$ ao longo de uma faixa de concentrações de DODAB e, portanto, de relações de área $\mathrm{R}$ em diferentes concentrações de $\mathrm{KCl}$. Cada valor de $\mathrm{R}$ foi calculado a partir de $0,0.05,0.1,0.2,0.3,0.5$, 0.6 ou $1.0 \mathrm{mM}$ de concentração final de DODAB no tubo.

As imagens fotográficas tiradas das misturas ilustraram situações de extremos como completa sedimentação produzindo um sobrenadante transparente (devido à formação de agregados grandes e pesados) ou ausência de sedimentação com dispersões de turbidez comparável à da dispersão de sílica sem $\mathrm{DODAB}$ na primeira coluna à esquerda onde $\mathrm{R}=0$ (Figura 3.2.3). Em toda a faixa de concentrações de $\mathrm{KCl}$ testadas, acima de valores de $\mathrm{R}=1 \mathrm{a}$ 
sedimentação estava ausente e a estabilidade coloidal foi excelente. A alta estabilidade coloidal a partir de $\mathrm{R}=1$ em baixa força iônica pode eventualmente ser explicada pela fusão de discos de bicamadas adsorvidos separadamente na superfície da sílica induzida pelo aumento de polaridade da solução e aumento de interação hidrofóbica entre fragmentos adsorvidos adjacentes. A alta estabilidade coloidal a partir de $\mathrm{R}=1$ pode se tornar um critério importante para identificar um recobrimento com bicamada contínua sobre partículas.

\section{4 - Conclusões}

As isotermas mostraram uma elevada afinidade de fragmentos de bicamadas de DODAB pela superfície da sílica nas concentrações de $\mathrm{KCl}$ empregadas, com a adsorção aumentando com a força iônica.

Existe uma dependência direta entre a densidade de carga superficial da sílica e a adsorção de DODAB em sua superfície, sugerindo um papel central das forças iônicas de atração eletrostática na determinação da adsorção.

A agregação máxima de partículas foi detectada em valores de razão de áreas $(\mathrm{R})$ iguais a 0.5 onde o potencial-zeta $(\zeta)$ do sistema é zero. A minimização da agregação acompanhada da desagregação começa a ocorrer a partir de $\mathrm{R}=1$ onde $\zeta$ é positivo.

Em baixa força iônica, a maior estabilidade coloidal da sílica, vista como a menor sedimentação em presença de fragmentos de bicamadas de DODAB, ocorreu a partir de $\mathrm{R} \geq$ 1, ou seja, a partir da equivalência das áreas totais de bicamadas e sílica.

\section{5 - Perspectivas}

- Elevação do recobrimento das superfícies de sílica atualmente alcançado através da elevação da carga superficial da sílica por aumento de $\mathrm{pH}$;

- Utilização do marcador MC540 (merocianina) no acompanhamento de novas cinéticas de adsorção de vesículas sonicadas em superfícies de sílica para elucidar o desenrolar do recobrimento assim como a disposição final dos fragmentos na superfície.

- Realização de ensaios visando a dessorção de bicamadas de DODAB da superfície de sílica através da adição de concentrações crescentes de força iônica, com o objetivo de estudar o grau de recobrimento da superfície pelas bicamadas. Uma dessorção resultante da adição de $\mathrm{KCl}$ indica a presença de espaços na superfície de sílica não recobertos por 
bicamadas de DODAB já que para uma bicamada perfeitamente selada depositada sobre a sílica, os íons provenientes do sal seriam impermeáveis.

- Realizar estudos de adsorção de bicamadas de fosfolípides neutros como fosfatidilcolina (PC) sobre a superfície negativamente carregada da sílica.

\section{6 - Referências bibliográficas}

ANDERSSON, M.; HAMMARSTRÖM, L.; EDWARDS, K. Effect of bilayer phase transitions on vesicle structure and its influence on the kinetics of viologen reduction. $\mathbf{J}$. Phys. Chem. 99 (39): 14531-14538 1995.

BANGHAM, A.D.; DE GIER, J.; GREVILLE, G.D. Osmotic properties and water permeability of phospolipid liquid crystals. Chem. Phys. Lipids 1: 225-246 1967.

BATZRI, S; KORN, E.D. Single bilayer liposomes prepared without sonication. Biochim. Biophys. Acta 298 (4): 1015-1019 1973.

BLANDAMER, M.J.; BRIGGS, B.; CULLIS, P.M.; ENGBERTS, J.B.F.N. Gel to liquidcrystal transitions in synthetic amphiphile vesicles. Chem. Soc. Rev. 24 (4): 251-\& AUG 1995.

BROOKHAVEN, INSTRUMENTS CORPORATION. Instruction Manual for BI-MAS Multi Angle Sizing Option on the ZetaPlus. Brookhaven Corporate Park, Holtsville NY USA 1995.

BROOKHAVEN, INSTRUMENTS CORPORATION. Instruction Manual for ZetaPlus Zeta Potential Analyzer. Brookhaven Corporate Park, Holtsville NY USA 1997.

BRUNAUER, S.; EMMETT, P.H.; TELLER, E. Adsorption of gases in multimolecular layers. J. Am. Chem. Soc. 60: 309-319 1938.

BURANDA, T.; HUANG, J.; RAMARAO, G.V.; ISTA, L.K.; LARSON, R.S.; WARD, T.L.; SKLAR, L.A.; LOPEZ, G.P. Biomimetic molecular assemblies on glass and mesoporous sílica microbeads for biotechnology. Langmuir 19 (5): 1654-1663 2003.

CARMONA-RIBEIRO, A.M.; CHAIMOVICH, H. Preparation and characterization of large dioctadecyldimethylammonium chloride liposomes and comparison with small sonicated vesicles. Biochim. Biophys. Acta 733 (1): 172-179 1983.

CARMONA-RIBEIRO, A.M., YOSHIDA, L.S.; SESSO, A.; CHAIMOVICH, H. Permeabilities and stabilities of large dihexadecylphosphate and dioctadecyldimethylammonium chloride vesicles. J. Colloid Interf. Sci. 100 (2): 433-443 1984.

CARMONA-RIBEIRO, A.M.; CHAIMOVICH, H. Salt-induced aggregation and fusion of dioctadecyldimethylammonium chloride and sodium dihexadecylphosphate vesicles. Biophys. J. 50 (4): 621-628 OCT 1986. 
CARMONA-RIBEIRO, A.M.; CASTUMA, C.E.; SESSO, A.; SCHREIER, S. Bilayer structure and stability in dihexadecyl phosphate dispersions. J. Phys. Chem. 95 (13): 5361 5366 JUN 271991.

CARMONA-RIBEIRO, A.M. Synthetic amphiphile vesicles. Chem. Soc. Rev. 21 (3): 209214 SEP 1992.

CARMONA-RIBEIRO, A.M. Does DLVO account for interaction between charged spheric vesicles? J. Phys. Chem. 96 (23): 9555-9557 NOV 121992.

CARMONA-RIBEIRO, A.M. Interaction between charged spherical vesicles. J. Phys. Chem. 97 (45): 11843-11846 NOV 111993.

CARMONA-RIBEIRO, A.M. Reply to comment on "Does DLVO account for interaction between charged spheric vesicles?” J. Phys. Chem. 97 (16): 4247-4247 APR 221993.

CARMONA-RIBEIRO, A.M. Bilayer vesicles and lipossomes as interface agents. Chem. Soc. Rev. 30: 241-247 2001.

CREMER, P.S.; BOXER, S.G. Formation and spreading of lipid bilayers on planar glass supports. J. Phys. Chem. B 103 (13): 2554-2559 1999.

DEAMER, D.; BANGHAM, A.D. Large volume liposomes by an ether vaporization method. Biochim. Biophys. Acta 443 (3): 629-634 1976.

DEGUSSA S/A. Basic characteristics of AEROSIL ${ }^{\circledR}$. Technical Bulletin Pigments 11 (4): AUG 1993.

EIBL, H.; BLUME, A. Influence of charge on phosphatidic-acid bilayer membranes. Biochim. Biophys. Acta 553 (3): 476-488 1979.

EVANS, D.F.; WENNERSTRÖM, H. The colloidal domain - Where physics, chemistry, biology and technology meet (1): VHC Publishers, Inc. 1994.

GENNIS, R.B. Biomembranes: molecular structure and function New York, Springer Verlag, Inc. 1989.

GILES, C.H.; MACEWAN, T.H.; NAKHWA, S.N.; SMITH, D. Studies in adsorption. Part 11. A system of classification of solutions adsorption isotherms, and its use in diagnosis of adsorption mechanisms and in measurements of specifics surface areas of solids. J. Chem. Soc. (OCT): 3973-3993 1960.

GRANELI, A.; RYDSTROM, J.; KASEMO, B.; HOOK, F. Formation of supported lipid bilayer membranes on $\mathrm{SiO}_{2}$ from proteoliposomes containing transmembrane proteins. Langmuir 19 (3): 842-850 2003.

GROVES, J.T.; BOXER, S.G. Micropattern formation in supported lipid membranes. Acc. Chem. Res. 35 (3): 149-157 2002.

HAMMARSTRÖM, L.; VELIKIAN, I.; KARLSSON, G.; EDWARDS, K. Cryo-TEM evidence: sonication of dihexadecylphosphate does not produce closed bilayers with smooth curvature. Langmuir 11 (2): 408-410 1995. 
HANUS, L.H; PLOEHN, H.J. Conversion of intensity-averaged photon correlation spectroscopy measurements to number-averaged particle size distributions. 1. Theoretical development. Langmuir 15 (9): 3091-3100 APR 271999.

HIEMENZ, P.C. Principles of Colloid and Surface Chemistry. (2): New York, Marcel 1986.

HUANG, C.H. Studies on phosphatidylcholine vesicles. Formation and physical characteristics. Biochemistry 8 (1): 344-\& 1969.

ISRAELACHVILI, J.N. Intermolecular and Surface Forces (2): London, Academic Press 1992.

ISRAELACHVILI, J.N.; MITCHELL D.J., NINHAM B.W. Theory of self-assembly of lipid bilayers and vesicles. Biochim. Biophys. Acta 470 (2): 185-201 1977.

ISRAELACHVILI, J.N; WENNERSTRÖM, H. Hydration of steric forces between amphiphilic surfaces. Langmuir 6 (4): 873-876 APR 1990.

JASS, J.; TJÄRNHAGE, T.; PUU, G. From liposomes to supported, planar bilayer structures on hydrophilic and hydrophobic surfaces: an atomic force microscopy study. Biophys. J. 79: 3153-31632000.

JAURAND M.C.; BAILLIF P.; THOMASSIN J.H.; et al. X-ray Photoelectron-spectroscopy and chemical study of the adsorption of biological molecules on chrysotile asbestos surface. $\mathbf{J}$. Colloid. Interf. Sci. 95 (1): 1-9 1983.

KANO, K.; ROMERO, A.; DJERMOUNI, B.; ACHE, H.; FENDLER, J.H. Characterization of surfactant vesicle as a membrane mimetic agent. 2. temperature-dependant changes of turbidity, viscosity, fluorescence polarization of 2 methylantracene, and positron annihilation in sonicated dioctadecyldimethylammoniun chloride. J. Am. Chem. Soc. 101 (15): 403040371979.

KELLER, C.A.; GLASMÄSTAR, K.; ZHDANOV, V.P.; KASEMO, B. Formation of supported membranes from vesicles. Phys. Rev. Lett. 84 (23): 5443-5446 2000.

KLEE, B.; JOHN, E.; JÄHNIG, F. A biosensor based on the membrane protein lactose permease. Sensors and Actuators B 6: 376-379 1992.

KLEE, B.; DUVENECK, G.L.; OROSZLAN, P.; EHRAT, M.; WIDMER, H.M. A model system for the development of na optical biosensor based on lipid membranes and membranebound receptors. Sensors and Actuators B 29: 307-311 1995.

KUNITAKE, T.; OKAHATA, Y.; TAMAKI, K.; KUMAMARU, F.; TAKAYANAGI, M. Formation of the bilayer membrane from a series of quaternary ammonium salts. Chem. Lett. (4): 387-390 1977.

LASIC, D.D. Sterically stabilized vesicles. Angew. Chem. Int. Edit. Engl. 33 (17): 16851698 SEP 161994.

LEE, A.G. Lipid phase transitions and phase diagrams. I. Lipids phase transition. Biochim. Biophys. Acta 472 (2): 237-281 1977. 
LEE, T.-H.; MOZSOLITS, H.; AGUILAR, M.-I. Measurement of the affinity of melittin for zwitterionic and anionic membranes using immobilized lipid biosensors. J. Peptide Res. 58: 464-476 2001.

LEONENKO, Z.V.; CARNINI, A.; CRAMB, D.T. Supported planar bilayer formation by vesicle fusion: the interaction of phospholipid vesicles with surfaces and the effect of gramicidin on bilayer properties using atomic force microscopy. Biochim. Biophys. Acta 1509: 131-147 2000.

LI, B.Q.; RUCKENSTEIN, E. Adsorption of ionic surfactants on charged solid surfaces from aqueous solutions. Langmuir 12 (21): 5052-5063 OCT 161996.

LIPTROT, G.F. Modern Inorganic Chemistry (4): London, Unwin Hyman Limited 1989.

LOIDL-STAHLHOFEN, A.; SCHMITT, J.; NOLLER, J.; HARTMANN, T.; BRODOWSKY, H.; SCHMITT, W.; KELDENICH, J. Solid-supported biomolecules on modified silica surfaces - A tool for fast physicochemical characterization and highthroughput screening. Advan. Mater. 13 (23): 1829-1834 DEC 2001.

MILONJIĆ, S. Determination of surface ionization and complexation constants at colloidal silica/electrolyte interface. Colloid. Surface. 23 (4): 301-312 APR 1987.

MORTARA, R.A.; QUINA, F.H.; CHAIMOVICH, H. Formation of closed vesicles from a simple phosphate diester - Preparation and some properties of vesicles of dihexadecyl phosphate. Biochem. Bioph. Res. Co. 81 (4): 1080-1086 1978.

MORTIMER, C. Chemistry-A Conceptual Approach (2): New York, D. Van Nostrand Company 1971.

MURASE, N.; GONDA, K. Adsorption of liposomes by clay. J. Biochem. Tokyo 92 (1): 271-273 1982.

OTTEWILL, R.H. Surfactants - Introduction in: TADROS, TH. F. Surfactants London, Academic Press: 1-18 1984.

PANSU, R.M.; ARRIO, B.; RONCIN, J.; FAURE, J. Vesicles versus membrane fragments in DODAC suspensions. J. Phys. Chem. 94 (2): 796-801 JAN 251990.

RAPUANO, R.; CARMONA-RIBEIRO, A.M. Physical adsorption of bilayer membranes on sílica. J. Colloid Interface Sci. 193: 104-111 1997.

RAPUANO, R.; CARMONA-RIBEIRO, A.M. Supported bilayers on silica. J. Colloid Interface Sci. 226: 299-307 2000.

RAPUANO, R. Interações entre vesículas sintéticas ou fosfolipídicas e superfícies de óxido de silício. Dissertação de Mestrado - IQUSP - 2000.

REVIAKINE, .I; BRISSON, A. Formation of supported phospholipid bilayers from unilamellar vesicles investigated by atomic force microscopy. Langmuir 16 (4): 1806-1815 2000 . 
SCHALES, O.; SCHALES S.S. A simple and accurate method for determination of chloride in biological fluids. J. Biol. Chem. 140: 879-884 1941.

SCHULLERY, S.E.; GARZANITI, J.P. Studies on phosphatidylcholine models membranes. I. Size-Heterogeneity effect on permeability measurements. Chem. Phys. Lipids 12 (2): 75 951974.

SEARS, G.W. Determination of specific surface area colloidal silica by titration with sodium hydroxide. Anal. Chem. 28 (12): 1981-1983 1956.

SHARMA, B.G.; BASU, S.; SHARMA, M.M. Characterization of adsorbed ionic surfactants on a mica substrate. Langmuir 12 (26): 6506-6512 DEC 251996.

SHILLCOCK, J.C.; LIPOWSKY, R. Equilibrium structure and lateral stress distribution of amphiphilic bilayers from dissipative particle dynamics simulations. J. Chem. Phys. 117 (10): 5048-5061 2002.

SICCHIEROLLI, S.M.; CARMONA-RIBEIRO, A.M. Incorporation of the cholera-toxin receptor in phospholipid-covered polystyrene microspheres. Colloid. Surface. B 5 (1-2): 57 61 SEP 251995.

SICCHIEROLLI, S.M.; CARMONA-RIBEIRO, A.M. Biomolecular recognition at phospholipid-covered polystyrene microspheres. J. Phys. Chem. B 100 (41): 16771-16775 OCT 101996.

STELMO, M.; CHAIMOVICH, H.; CUCCOVIA, I.M. Quantitative-determination of alkylammonium amphiphiles using neutral detergents. J. Colloid Interf. Sci. 117 (1): 200204 MAY 1987.

SUGAO, N.; SUGAWARA, M.; MINAMI, H.; UTO, M.; UMEZAWA, Y. Na ${ }^{+}$D-Glucose cotransporter based bilayer lipid membrane sensor for D-Glucose. Anal. Chem. 65 (4): 3633691995

TADROS, T.F.; LYKLEMA, J. Adsorption of potential-determining ions at the silicaaqueous electrolyte interface and the role of some cations. J. Electroanal. Chem. 17 (3-4): 267-\& 1968.

TANFORD, C. The hydrophobic effect. Formation of micelles and biological membranes (2): New York, John Wiley \& Sons, Inc. 1980.

TSURUTA, L.R.; CARMONA-RIBEIRO, A.M. Counterion Effects on Colloid Stability of Cationic Vesicles and Bilayer-Covered Polystyrene Microspheres. J. Phys. Chem. 100 (17): 7130-7134 1996.

VAGIN, M.Y.; KARYAKIN, A.A.; HIANIK, T. Surfactant bilayers for the direct electrochemical detection of affinity interactions. Bioelectrochemistry 56: 91-93 2002.

WÄENGNERUD, P.; JÖENSSON, B. Adsorption of ionic amphiphiles as bilayers on charged surfaces. Langmuir 10 (9): 3268-3278 SEP 1994. 
7 - Agradecimentos

Ao CNPq pela bolsa.

À FAPESP pelos auxílios.

Aos professores do IQUSP pelo ensino.

À PROFA. CARMONA-RIBEIRO PELA ORIENTAÇÃO.

AO APOIO E CONFIANÇA DOS COLEGAS DO LABORATÓRIO (CLÁUdIA, DÉBORA, EDLA, FELIPE, NILTON E LUIS FERNANDO)

PARA A MINHA MÃE, PARA O MEU PAI, E PARA MIM MESMO. 


\section{CURRICULUM VitAE}

(OUTUBRO/2003)

Nome: Sérgio de Paula Moura.

Local e data de nascimento: São Paulo, SP, Brasil; 17 de janeiro de 1977.

\section{EDUCAÇÃo}

Primeiro Grau:

Colégio São Luís, São Paulo, SP.

Segundo Grau:

Colégio São Luís, São Paulo, SP.

Terceiro Grau:

Fundação Armando Ávares Penteado, FAAP, São Paulo, SP.

Engenharia Química em dezembro de 2000.

OCUPAÇÃo ATUAL: Bolsista de doutorado / FAPESP

\section{PublicaÇões}

NOVAK, ESTELA; BRANDINE, C.; CARMO, A.D.; MOURA, S.; NERY, A. "In Vivo" transfection of SP1 transcription factor decoy in melanoma tumor. J Gene Med. Supplement 2 (5): OCT 2000.

MOURA, S.P.; CARMONA-RIBEIRO, A.M. Cationic Bilayer Fragments on Silica at Low Ionic Strength: Competitive Adsorption and Colloid Stability. Langmuir, 19 (17): 6664-6667 2003.

\section{APRESEnTAÇÃo de TrabalHo}

Apresentação do trabalho "The effect of cationic bilayers on colloid stability of silica" na XXXIII Reunião Anual da Sociedade Brasileira de Bioquímica e Biologia Molecular (SBBq), em Caxambu, de 17-22 de maio de 2003.

\section{PARTicipação em Congresso}

Participação na XXXIII Reunião anual da Sociedade Brasileira de Bioquímica e Biologia Molecular (SBBq) realizada em Caxambu, no período de 17-22 de maio de 2003.

\section{Curso Realizado}

Aula teórica "Drogas e Bioquímica: Qual é o barato?" desenvolvida no curso prático "Ensino de Bioquímica", ministrada para professores da cadeia pública de ensino médio do Estado de São Paulo, com supervisão do Prof. Bayardo B. Torres, realizado no Instituto de Química, em São Paulo, SP, de 6 a 10 de janeiro de 2003. 